\title{
Article \\ Inhibition of Mitochondrial Metabolism Leads to Selective Eradication of Cells Adapted to Acidic Microenvironment
}

\author{
Martina Koncošová ${ }^{1}$, Nikola Vrzáčková ${ }^{1}$, Ivana Kř̌̌žová ${ }^{2}{ }^{\circledR}$, Petra Tomášová ${ }^{3,4}$, Silvie Rimpelová ${ }^{1} \mathbb{}$,

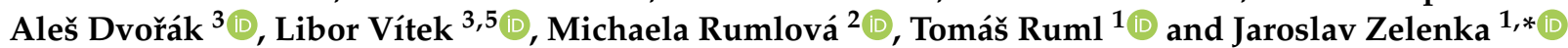 \\ 1 Department of Biochemistry and Microbiology, University of Chemistry and Technology Prague, \\ 16628 Prague, Czech Republic; martina.koncosova@vscht.cz (M.K.); nikola.vrzackova@vscht.cz (N.V.); \\ silvie.rimpelova@vscht.cz (S.R.); tomas.ruml@vscht.cz (T.R.) \\ 2 Department of Biotechnology, University of Chemistry and Technology Prague, 16628 Prague, \\ Czech Republic; ivana.krizova@vscht.cz (I.K.); michaela.rumlova@vscht.cz (M.R.) \\ 3 Institute of Medical Biochemistry and Laboratory Diagnostics, Faculty General Hospital and 1st Faculty of \\ Medicine, Charles University, 12000 Prague, Czech Republic; petra.lacinova@lf1.cuni.cz (P.T.); \\ ales.dvorak@lf1.cuni.cz (A.D.); libor.vitek@lf1.cuni.cz (L.V.) \\ 4 Institute of Microbiology, The Czech Academy of Sciences, 14000 Prague, Czech Republic \\ 5 4th Department of Internal Medicine, Faculty General Hospital and 1st Faculty of Medicine, \\ Charles University, 12000 Prague, Czech Republic \\ * Correspondence: jaroslav.zelenka@vscht.cz; Tel.: +420-22044-5207
}

\section{check for} updates

Citation: Koncošová, M.; Vrzáčková, N.; Kř́ižová, I.; Tomášová, P.; Rimpelová, S.; Dvořák, A.; Vítek, L.; Rumlová, M.; Ruml, T.; Zelenka, J. Inhibition of Mitochondrial Metabolism Leads to Selective Eradication of Cells Adapted to Acidic Microenvironment. Int. J. Mol. Sci. 2021, 22, 10790. https://doi.org/ 10.3390/ijms221910790

Academic Editor: Biana Godin

Received: 3 September 2021

Accepted: 2 October 2021

Published: 6 October 2021

Publisher's Note: MDPI stays neutral with regard to jurisdictional claims in published maps and institutional affiliations.

Copyright: (c) 2021 by the authors. Licensee MDPI, Basel, Switzerland. This article is an open access article distributed under the terms and conditions of the Creative Commons Attribution (CC BY) license (https:// creativecommons.org/licenses/by/ $4.0 /)$.
Abstract: Metabolic transformation of cancer cells leads to the accumulation of lactate and significant acidification in the tumor microenvironment. Both lactate and acidosis have a well-documented impact on cancer progression and negative patient prognosis. Here, we report that cancer cells adapted to acidosis are significantly more sensitive to oxidative damage induced by hydrogen peroxide, high-dose ascorbate, and photodynamic therapy. Higher lactate concentrations abrogate the sensitization. Mechanistically, acidosis leads to a drop in antioxidant capacity caused by a compromised supply of nicotinamide adenine dinucleotide phosphate (NADPH) derived from glucose metabolism. However, lactate metabolism in the Krebs cycle restores NADPH supply and antioxidant capacity. CPI-613 (devimistat), an anticancer drug candidate, selectively eradicates the cells adapted to acidosis through inhibition of the Krebs cycle and induction of oxidative stress while completely abrogating the protective effect of lactate. Simultaneous cell treatment with tetracycline, an inhibitor of the mitochondrial proteosynthesis, further enhances the cytotoxic effect of CPI613 under acidosis and in tumor spheroids. While there have been numerous attempts to treat cancer by neutralizing the $\mathrm{pH}$ of the tumor microenvironment, we alternatively suggest considering tumor acidosis as the Achilles' heel of cancer as it enables selective therapeutic induction of lethal oxidative stress.

Keywords: tumor microenvironment; mitochondria; acidosis; photodynamic therapy; CPI-613; tetracycline; lactate; cancer; bioenergetics; therapy

\section{Introduction}

The metabolic transformation has been recently included between the hallmarks of cancer cells. Its principal component, the Warburg effect, is characterized by the enhanced utilization of glucose and the excessive production of lactate even in the presence of oxygen and a competent mitochondrial respiratory chain [1]. The resulting accumulation of lactate is accompanied by the acidification of the tumor microenvironment which is further pronounced by tumor hypercapnia and the activity of carbonic anhydrases IX and XII (CAIX, CAXII) intended to ameliorate intracellular acidosis on account of the extracellular $\mathrm{pH}[2]$.

The presence of lactic acidosis selects a subpopulation of oxidative cancer cells with enhanced activity of mitochondrial respiratory chain and malignant potential [3-5]. Both 
lactate content and acidity of the tumor microenvironment have been associated with the occurrence of metastases and poor patient prognosis [6-9]. Moreover, lactic acidosis plays a well-documented role in tumor neoangiogenesis and the induction of tolerance by infiltrated immune cells [10-12]. Therefore, CAIX/CAXII [13,14], lactate dehydrogenase [15-17], monocarboxylate transporters responsible for the import/export of lactate and $\mathrm{H}^{+}$through the cytoplasmic membrane [17-19], and other components involved in the formation of the lactic acidosis have been pharmacologically targeted in an attempt to block the cancer progression. However, none of these approaches achieved the phase III clinical trial.

On the other hand, cancer cells are also characterized by enhanced production of reactive oxygen species (ROS) triggered by the combination of metabolic transformation, oncogenic signaling, and eventually mutations in metabolic genes including mitochondrial DNA (deoxyribonucleic acid) [20]. The compensation of resulting oxidative stress with a strong antioxidant response is critical for cell survival and cancer progression [21]. Moreover, high antioxidative capacity stimulates tumor metastasis [22,23] and cancer resistance to therapy $[24,25]$.

Interestingly, both the elevation of extracellular lactate [26] and acidosis [27,28] have been independently demonstrated to enhance ROS production and antioxidant response. A few works investigating the effect of lactic acidosis on cell viability and resistance to oxidative stress pointed out the importance of genetic background and the difference between simple acidosis and lactic acidosis [28,29]. This study aimed to separately identify the effects of lactate and acidosis on the sensitivity of cancer cells to oxidative stress-based anticancer therapies.

\section{Results and Discussion}

\subsection{The Effects of Lactic Acidosis on the Cell Sensitivity to Oxidative Insult}

Lactate and acidosis were linked to ROS burst and upregulation of antioxidant defense [26-28,30-32]. However, little is known about the individual effects of lactate and acidosis on cancer cell resistance to lethal oxidative stress. Therefore, in this study, human pancreatic PaTu-8902 cells were treated with cell culture media with different concentrations of the lactate anion and $\mathrm{pH}, 0-24 \mathrm{mM}$ and 6.8-7.4, respectively, for three days to enable metabolic adaptation. To approximate the physiological conditions of the human body, the medium with $5 \mathrm{mM}$ glucose and $0.5 \mathrm{mM}$ glutamine, which was exchanged daily, was employed. The whole experimental design is summarized in Figure A1 in Appendix A. The treatment with the experimental media resulted in only marginal changes in cell viability and the occurrence of apoptotic cells (Figure A2). Cells were subsequently exposed to $500 \mu \mathrm{M}$ hydrogen peroxide as an oxidative insult for $24 \mathrm{~h}$. There was a significant dosedependent relationship among $\mathrm{pH}$, lactate levels, and the observed decrease in cell viability. While acidosis significantly compromised cell viability, the presence of lactate anion has a protective effect. Importantly, the presence of lactate in acidic media significantly and dose-dependently mitigated the effect of acidosis on the cell sensitivity to oxidative stress (Figure 1A). This phenomenon was detected at a pH of 6.8 and a $12 \mathrm{mM}$ concentration of lactate, i.e., the conditions previously reported for the tumor microenvironment $[4,33,34]$. Therefore, the general validity of this phenomenon was demonstrated under these conditions using three different human cancer cell lines (PaTu-8902, cervix HeLa, and liver Hep G2), a noncancerous human dermal fibroblast (HDF) cell line, and several concentrations of hydrogen peroxide (Figure 1B-D). Although some variability regarding the magnitude of the effects and the overall sensitivity of the cell lines to hydrogen peroxide was observed, the sensitization under acidic conditions and its attenuation with lactate was confirmed in all cell lines including the noncancerous one. Live/dead staining correlated with the viability results, revealing a dramatic rise in the population of dead cells with increasing concentration of hydrogen peroxide (Figure A3). 

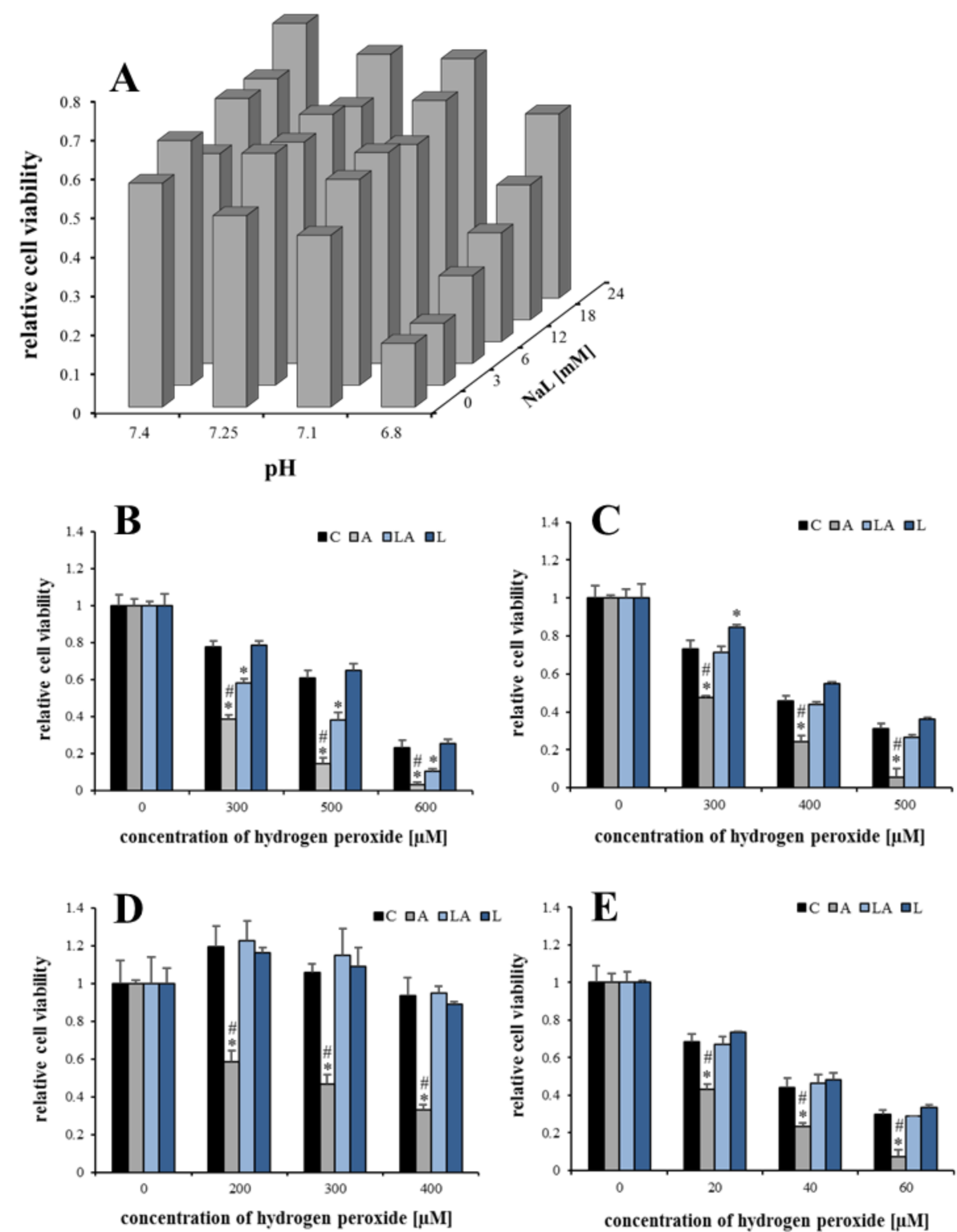

Figure 1. The effect of lactic acidosis on cell sensitivity to oxidative insult. (A) Viability of PaTu-8902 cells cultured in media of different $\mathrm{pH}$ and concentrations of lactate anion $(\mathrm{NaL})$ for $72 \mathrm{~h}$ and then treated with $500 \mu \mathrm{M}$ hydrogen peroxide. Viability of (B) PaTu-8902, (C) HeLa, (D) Hep G2, and (E) noncancerous HDF cells cultured in experimental media for $72 \mathrm{~h}$ and then treated with indicated concentrations of hydrogen peroxide. Viability was measured by resazurin assay. C, control; A, acidosis; LA, lactic acidosis; L, high lactate $\left({ }^{*} p<0.05\right.$ compared to $\mathrm{C}, \# p<0.05$ when comparing A and LA).

To establish whether these effects are directly caused by harmful extracellular conditions or whether they resulted from cell adaptation, PaTu-8902 cells were treated with the experimental media for various lengths of time before the treatment with hydrogen peroxide. The effects were observed already $6 \mathrm{~h}$ post-treatment with the experimental media (Figure 2A), although with a smaller magnitude than after $72 \mathrm{~h}$ (Figure 1B). In contrast, the treatment lasting 14 days further intensified the effects (Figure 2B) suggesting that the effects did not vanish during the long-term adaptation. When the cells were treated with the experimental media for $72 \mathrm{~h}$ and then with the control medium for $4 \mathrm{~h}$, the effect was still present, although with a smaller magnitude (Figure 2C). Thus, the effects resulted from cell adaptation to lactic acidosis rather than from the harmful effects of acidosis itself. 
Finally, the effects disappeared completely after $48 \mathrm{~h}$ from exchanging the experimental media for the control one (Figure 2D).

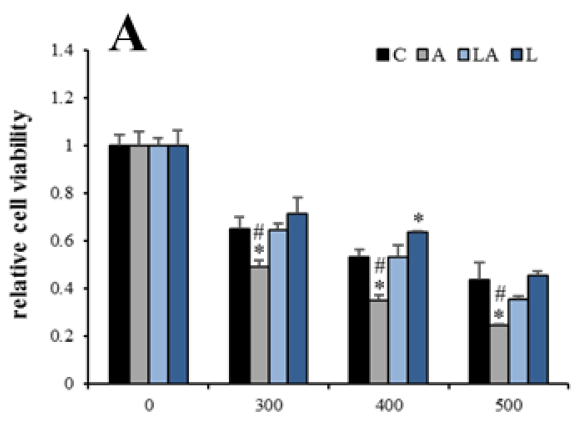

concentration of hydrogen peroxide $[\mu \mathrm{M}]$

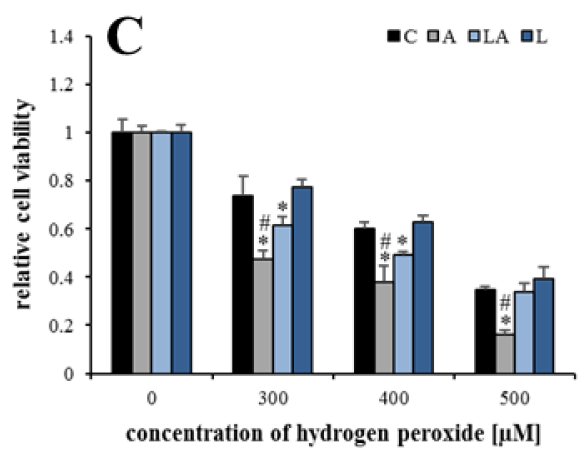

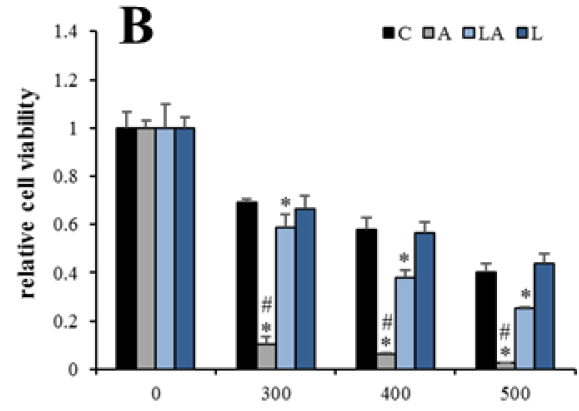

concentration of hydrogen peroxide $[\mu \mathrm{M}]$

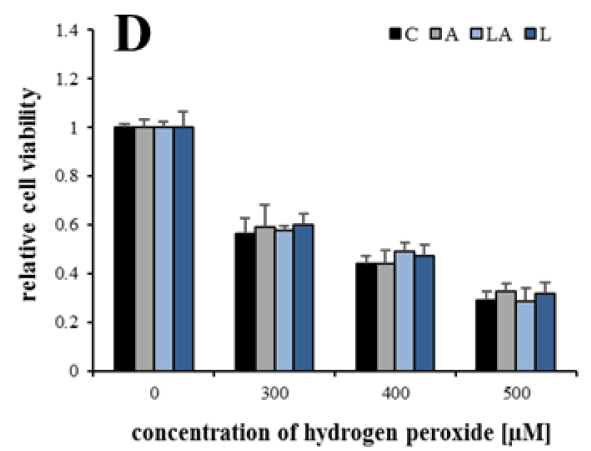

Figure 2. The effect of adaptation time on cell sensitivity to oxidative insult. PaTu-8902 cells were treated with experimental media for (A) $6 \mathrm{~h}$, (B) 14 days, and (C,D) $72 \mathrm{~h}$ followed by 4 and $48 \mathrm{~h}$ washout with the control medium, respectively. Then, the cells were treated with the indicated concentrations of hydrogen peroxide and their viability was measured by resazurin assay. $\mathrm{C}$, control; $\mathrm{A}$, acidosis; LA, lactic acidosis; $\mathrm{L}$, high lactate $\left({ }^{*} p<0.05\right.$ compared to $\mathrm{C}, \# p<0.05$ when comparing $\mathrm{A}$ and LA).

\subsection{The Effect of Lactic Acidosis on Cancer Cell Sensitivity to Therapy}

It has been demonstrated that some cancer therapies are accompanied by oxidative damage $[20,21]$. Therefore, the effects of lactate and acidosis on the cancer cell sensitivity to such therapies were investigated. PaTu-8902 cells treated with the experimental media for $72 \mathrm{~h}$ were exposed to X-ray irradiation (Figure 3A), doxorubicin (Adriamycin, Figure 3B), cytotoxic doses of ascorbate (vitamin C, Figure 3C), and photodynamic therapy (PDT) with three different photosensitizers pheophorbide $a$ (Figure 3D), molybdenum (Mo) cluster (Figure 3E), and porphyrin abbreviated as TIPPP $(5,10,15,20$ tetrakis(4-isopropylphosphinatophenyl)porphyrin, Figure 3F), previously characterized by our group [28-30].

Interestingly, no effects of the experimental media were observed for X-rays and doxorubicin that act mainly through the DNA damage accompanied by oxidative stress. On the contrary, cells adapted to acidosis were sensitized to pharmacological ascorbate and PDT, which are directly mediated by oxidative damage [35]. The presence of lactate again abrogated the effect of acidosis. The effects of the experimental media on cell sensitivity to PDT were demonstrated also for other cell lines (Figure A4). 

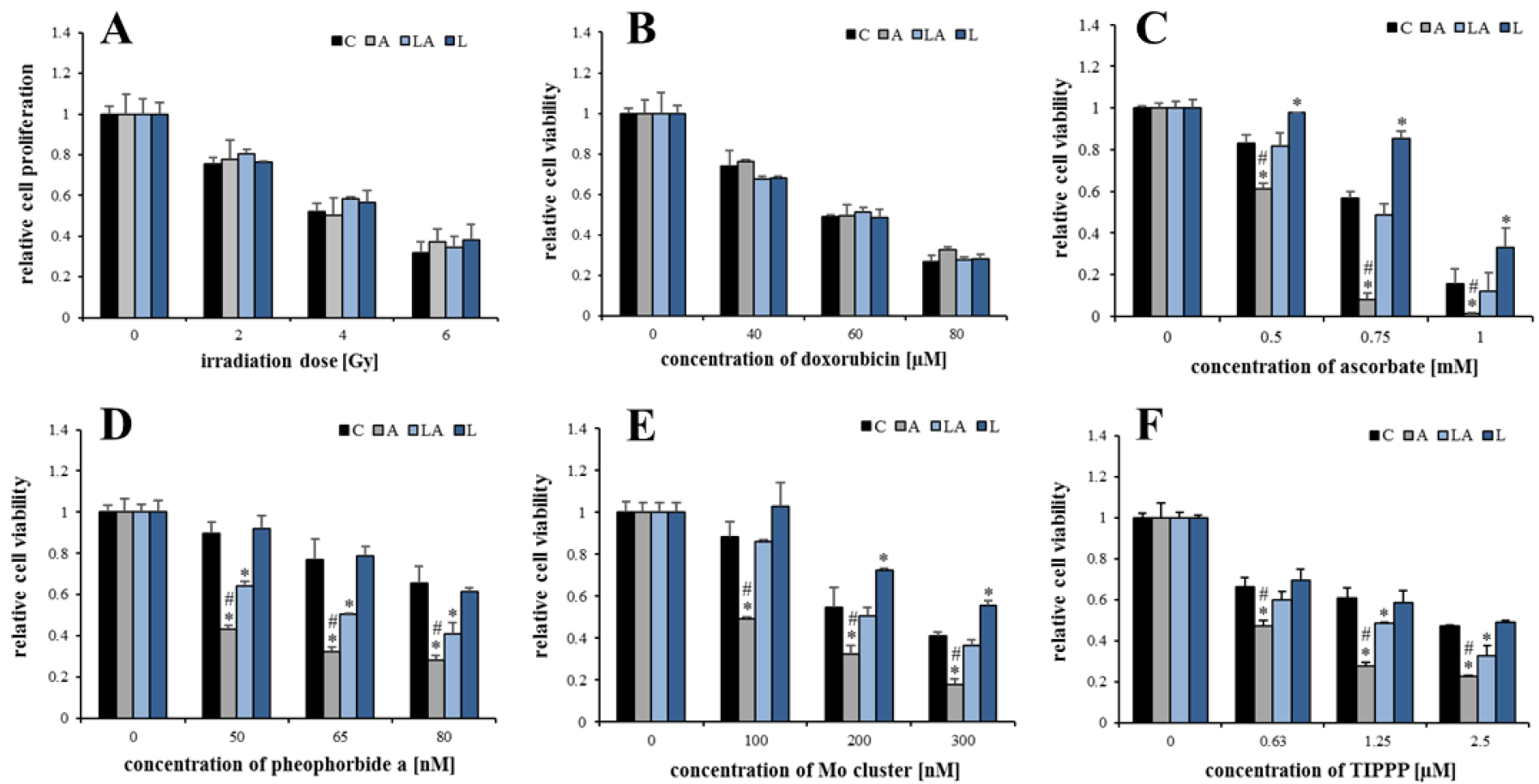

Figure 3. The effect of lactic acidosis on cancer cell sensitivity to radio-, chemo-, and phototherapy. PaTu-8902 cells were cultured in experimental media for $72 \mathrm{~h}$ and then treated with (A) X-ray irradiation, (B) doxorubicin, (C) pharmacological ascorbate, and (D-F) photodynamic therapy using pheophorbide $a$, Mo cluster, and 5,10,15,20-tetrakis(4isopropylphosphinatophenyl)porphyrin (TIPPP), respectively. The proliferation of irradiated cells after reseeding and subsequent $72 \mathrm{~h}$ incubation and viability of the rest after $24 \mathrm{~h}$ were measured by resazurin assay. C, control; A, acidosis; LA, lactic acidosis; $\mathrm{L}$, high lactate ( ${ }^{*} p<0.05$ compared to $\mathrm{C}$, \# $p<0.05$ when comparing A and LA).

\subsection{The Effect of Lactic Acidosis on Uptake and Localization of Photosensitizers}

The fluorescence and different physico-chemical properties of the used photosensitizers were utilized for the investigation, whether the observed effects of the experimental media are related to altered uptake or subcellular localization of the compounds used for the induction of oxidative damage. Via live-cell spinning disc confocal microscopy of HeLa cells, we have documented that pheophorbide $a$ (Figure 4A) and Mo cluster (Figure 4B) co-localized with mitochondria, while TIPPP co-localized with lysosomes (Figure 4C). No effect of the experimental media on the intracellular localization of the photosensitizers was detected.

In addition, the flow cytometry analysis with PaTu cells showed increased uptake of pheophorbide $a$ (Figure 4D) and TIPPP (Figure 4F) in the acidic medium. However, interestingly, the penetration of the Mo cluster (Figure 4E) was not affected by the experimental media. Furthermore, there was no effect of experimental media on cell size (Figure A5). Since the changes in the uptake of both porphyrins were insufficient to fully explain the effects of the experimental media, and the cell uptake of the Mo cluster was not affected at all, the observed effects are unlikely to be explained by a differential uptake of the employed compounds. 

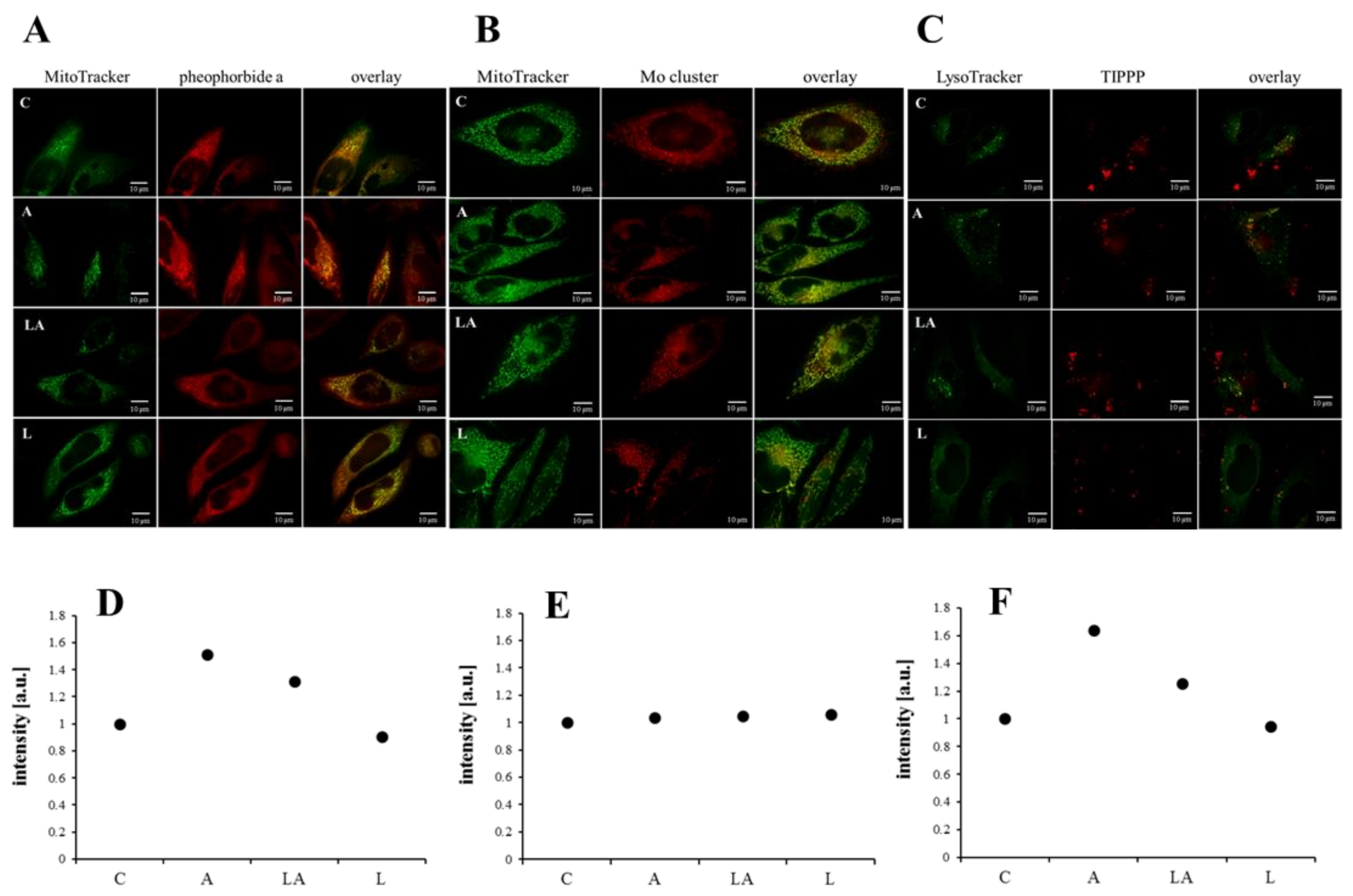

Figure 4. The effect of lactic acidosis on uptake and localization of photosensitizers in cancer cells. Localization of (A) pheophorbide $a$, (B) Mo cluster, and (C) 5,10,15,20-tetrakis(4-isopropylphosphinatophenyl)porphyrin (TIPPP) in HeLa cells treated with the experimental media for $72 \mathrm{~h}$. The photosensitizers (red emission) were co-localized with (A,B) MitoTracker ${ }^{\mathrm{TM}}$ Green FM or (C) LysoTracker ${ }^{\mathrm{TM}}$ Green DND-26 (both green emission) to visualize the subcellular localization. Uptake of (D) pheophorbide $a$, (E) Mo cluster, and (F) TIPPP in PaTu-8902 cells treated with the experimental media for $72 \mathrm{~h}$ measured by flow cytometry. C, control; A, acidosis; LA, lactic acidosis; L, high lactate.

\subsection{The Effect of Lactic Acidosis on Redox Homeostasis of the Cancer Cells}

Next, the role of cell redox homeostasis in differential sensitivity to oxidative insult was investigated. Determination of the total cellular antioxidant capacity revealed a significantly compromised antioxidant barrier in PaTu-8902 cells treated with the acidic medium (Figure 5A). The simultaneous presence of lactate significantly improved the antioxidant status of the cells. However, the concentration and redox status of glutathione, the essential intracellular antioxidant [21], were not consistently affected by the experimental media (Figure 5B).

Since the redox status of glutathione and other antioxidants is determined by continuous oxidation with ROS and reduction with NADPH [36], these variables were also studied. The levels of total intracellular NADPH were significantly decreased in acidic media, while the simultaneous presence of lactate significantly mitigated this effect (Figure 5C). Production of superoxide, the prime cellular ROS produced by mitochondria and NADPH oxidases [36], measured as oxidation of dihydroethidium probe, was not affected by the experimental media (Figure 5D). In contrast, the oxidation of $2^{\prime}, 7^{\prime}$-dichlorodihydrofluorescein (DCF), was significantly increased under acidosis, which was attenuated by the simultaneous presence of lactate (Figure 5E). The oxidation of DCF is thought to be caused by peroxyl radicals and other dangerous, short-lived products of the oxidative damage resulting from the breakthrough of the antioxidant barrier [37], which seems to be the case under acidic 
conditions. Therefore, these data suggest that the sensitization of the cells to oxidative insult in the acidic medium is mediated by compromised antioxidant machinery driven by insufficient levels of NADPH.
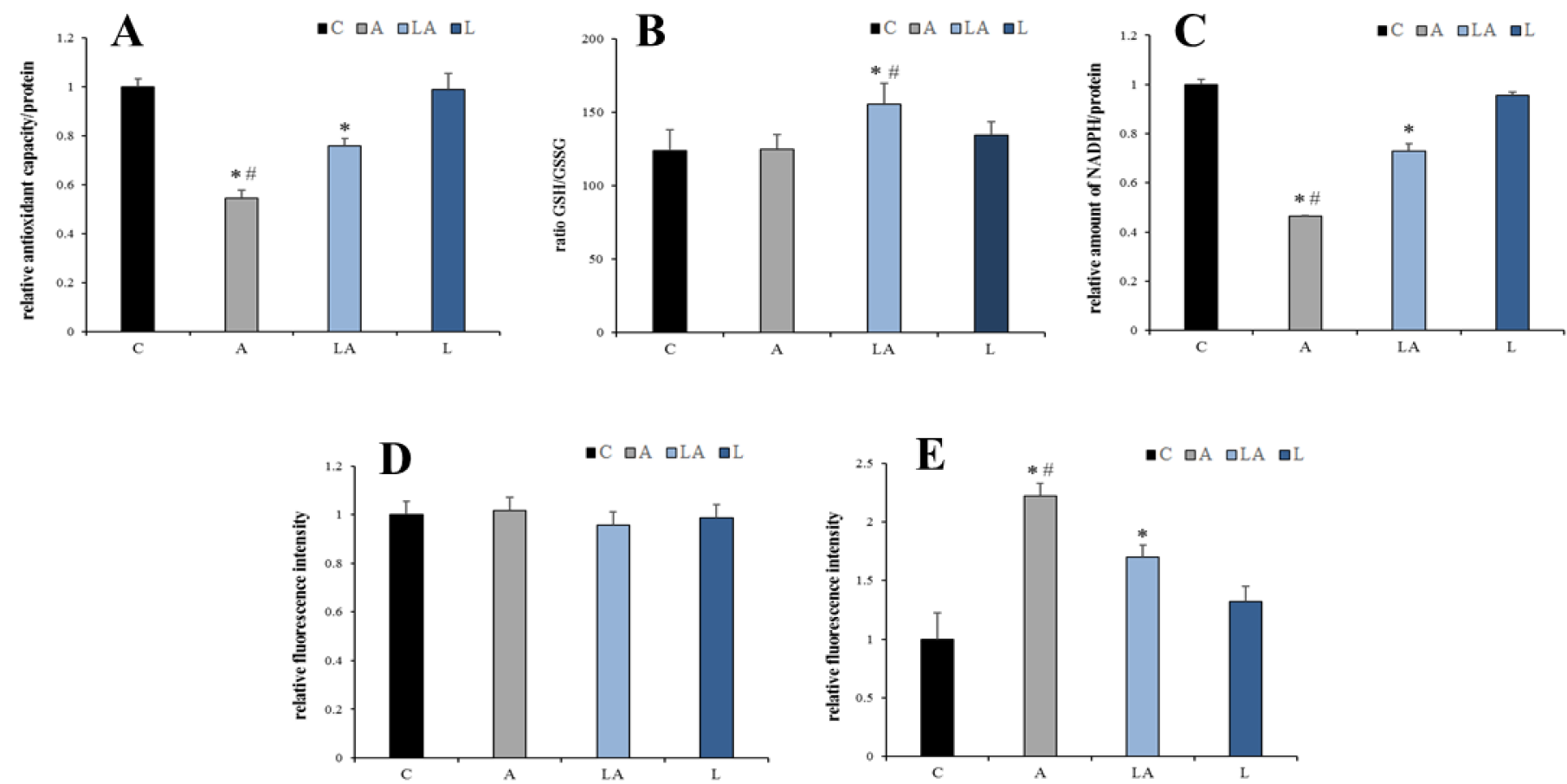

Figure 5. The effect of lactic acidosis on redox homeostasis of cancer cells. PaTu-8902 cells were treated with the experimental media for $72 \mathrm{~h}$ and (A) relative antioxidant capacity, (B) ratio of reduced (GSH) to oxidized (GSSG) glutathione in the cells, (C) relative concentration of NADPH, (D) oxidation of dihydroethidium, and (E) oxidation of $2^{\prime}, 7^{\prime}$-dichlorodihydrofluorescein measured as a relative fluorescence were determined. C, control; A, acidosis; LA, lactic acidosis; $\mathrm{L}$, high lactate ${ }^{*} p<0.05$ compared to $\mathrm{C}, \# p<0.05$ when comparing A and LA).

\subsection{The Effect of Lactic Acidosis on the Cancer Cell Metabolism}

Intracellular NADPH is regenerated by several cytoplasmic and mitochondrial metabolic pathways belonging to the central energetic metabolism [36] (Figure 6). Several authors described a significant metabolic rewiring of the cells under acidosis, especially increased lipid metabolism and activity of pathways known to produce NADPH $[27,28,32,38-40]$. Therefore, the effects of the experimental media on key characteristics of the cell bioenergetics were examined. The total cellular concentration of adenosine triphosphate (ATP) and the mitochondrial membrane potential dropped significantly under acidosis but not under lactic acidosis (Figure 7A,B), while the rate of oxygen consumption (Figure 7C), lactate production/utilization (Figure 7D), and glucose consumption (Figure 7E) were not significantly affected by $\mathrm{pH}$ of the experimental media. Importantly, acidosis in the absence of lactate significantly attenuated a red signal $(560 / 610 \mathrm{~nm})$ from Nile red staining of cells, which corresponds to the mass of phospholipid membranes (Figure 7F). The changes in green signal $(488 / 525 \mathrm{~nm})$ from Nile red corresponding to neutral lipid droplets (Figure A6) were not significant (data not shown). 
Based on these data, we hypothesized that the cell adaptation to acidosis is associated with enhanced cytoplasmic NADPH consumption for lipid-synthetic purposes, which requires surplus NADPH generation secured by mitochondrial metabolism of lactate. This idea was supported by performing the hydrogen peroxide challenge in the absence of glucose, the main source of cytoplasmic NADPH. The results showed that cells lacking glucose were generally much more sensitive to oxidative insult, while the effect of medium $\mathrm{pH}$ was minor. The presence of lactate again significantly rescued the cell viability (Figure $8 \mathrm{~A}$ ). In addition, cell treatment with a mitochondrial uncoupler carbonyl cyanide- $p$-trifluoromethoxyphenylhydrazone (FCCP), dissipating the mitochondrial membrane potential necessary for the regeneration of NADPH via nicotinamide nucleotide transhydrogenase (NNT, Figure 6), sensitized cells to oxidative stress, thus eradicating the acidosis-adapted cells independently on the presence of lactate even at the lowest concentrations of hydrogen peroxide (Figure 8B). The treatment with FCCP alone caused only a slight drop in the cell signal from the resazurin viability assay with no difference regarding the $\mathrm{pH}$ of the media (Figure $\mathrm{A7}$ ).

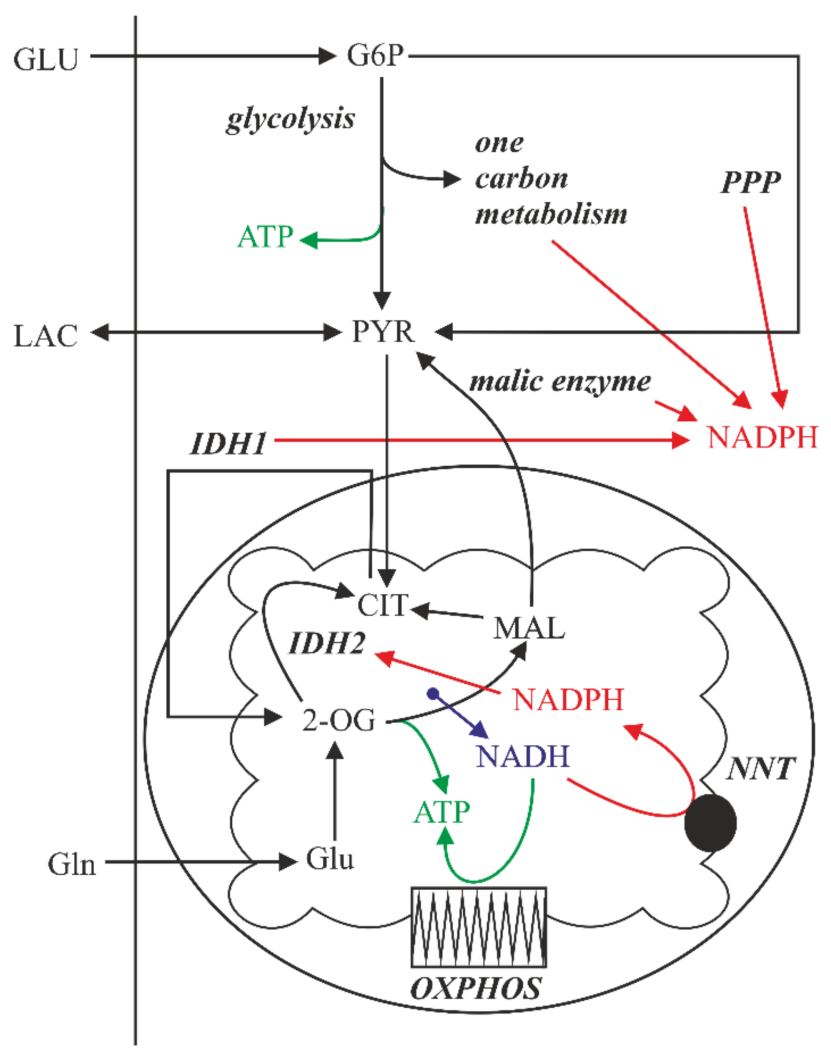

Figure 6. Partitioning of metabolic flow between the production of ATP and NADPH. ATPadenosine triphosphate, CIT-citrate, GLU—glucose, G6P-glucose-6-phosphate, Gln-glutamine, Glu—glutamate, IDH1(2)—isocitrate dehydrogenase 1(2), LAC—lactate, MAL—malate, NAD(P)H— nicotinamide adenine dinucleotide (phosphate), NNT—nicotinamide nucleotide transhydrogenase, 2-OG-2-oxoglutarate, OXPHOS-mitochondrial oxidative phosphorylation system, PPP — pentose phosphate pathway, PYR-pyruvate. 

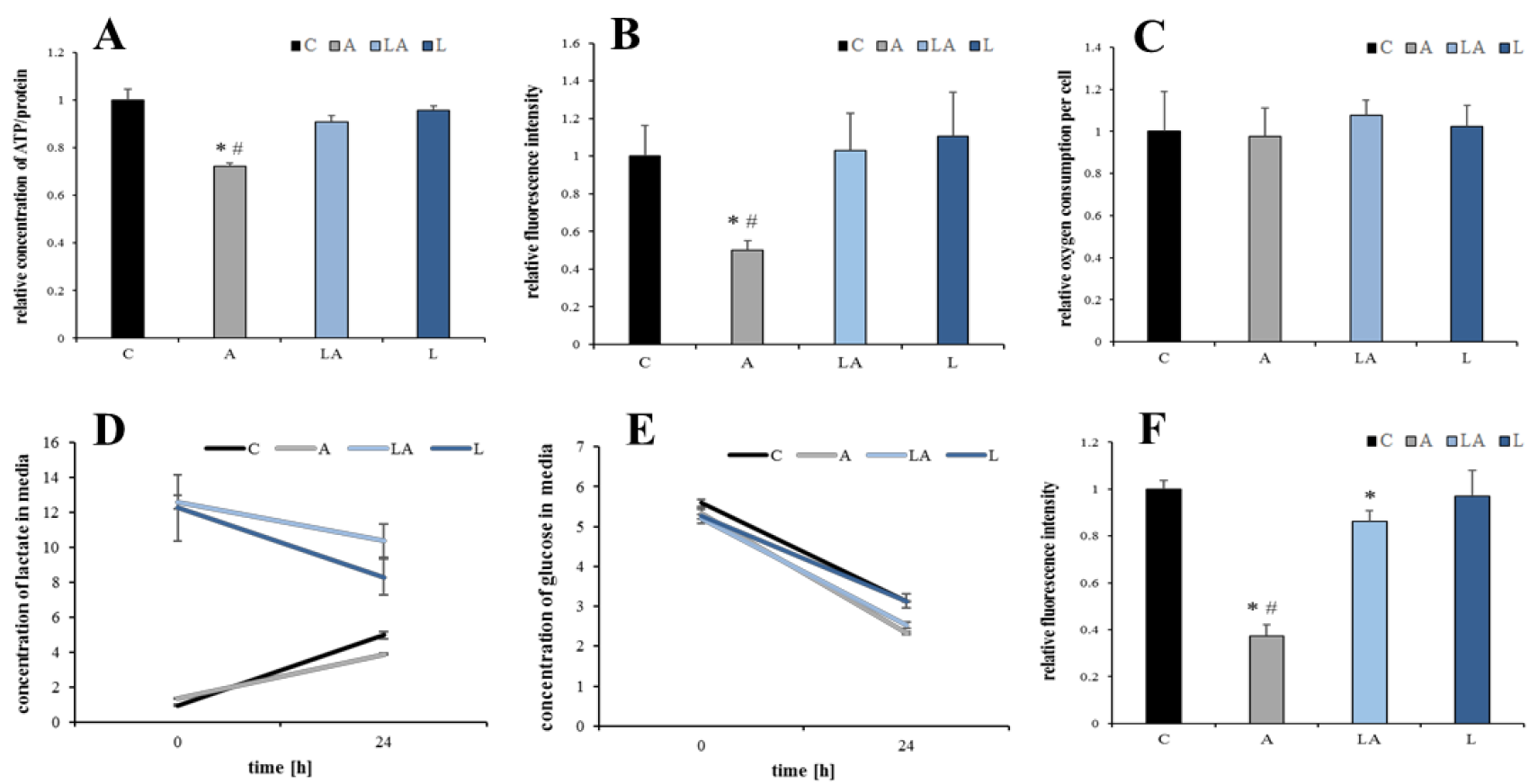

Figure 7. The effect of lactic acidosis on cancer cell metabolism. PaTu-8902 cells were treated with the experimental media for $72 \mathrm{~h}$ and (A) concentration of total cellular ATP, (B) mitochondrial membrane potential, (C) oxygen consumption, the changes in (D) lactate and (E) glucose levels in the culture media, and (F) mass of cellular phospholipids were determined. C, control; A, acidosis; LA, lactic acidosis; L, high lactate ( ${ }^{*} p<0.05$ compared to $\mathrm{C}, \# p<0.05$ when comparing A and LA).
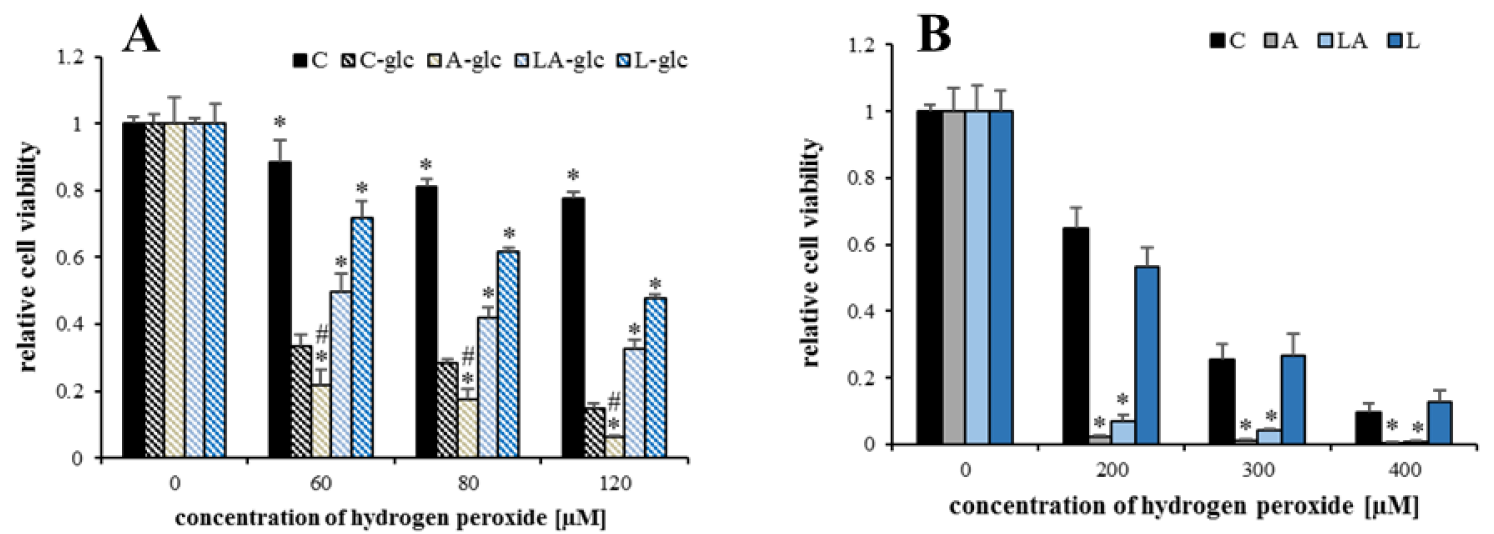

Figure 8. Synergic effects of lactic acidosis and metabolic manipulations. (A) The viability of PaTu-8902 cells treated with the experimental media lacking glucose for $72 \mathrm{~h}$ and challenged with the indicated concentrations of hydrogen peroxide. (B) The viability of PaTu-8902 cells was treated with experimental media and carbonyl cyanide- $p$-trifluoromethoxyphenylhydrazone (FCCP) for $72 \mathrm{~h}$ and challenged with indicated concentrations of hydrogen peroxide. Viability was measured by resazurin assay. C, control; A, acidosis; LA, lactic acidosis; $\mathrm{L}$, high lactate $\left({ }^{*} p<0.05\right.$ compared to $\mathrm{C}, \# p<0.05$ when comparing A and LA).

\subsection{Inhibition of Mitochondrial Metabolism under Acidosis}

The observed importance of mitochondrial metabolism motivated the search for an inhibitor capable to selectively kill the cells under acidic conditions even in the presence of lactate. Tetracycline antibiotics have been previously demonstrated to suppress cancer stem cells via inhibition of mitochondrial proteosynthesis [41]. The treatment of PaTu-8902 cells with the experimental media containing tetracycline for $72 \mathrm{~h}$ showed the same pattern of killing as the oxidative insults (Figure 9A). Importantly, the treatment with CPI-613, an inhibitor of the pyruvate dehydrogenase complex and $\alpha$-ketoglutarate dehydrogenase complex and a candidate drug against several types of cancer [www.clinicaltrials.gov [42-44], accessed on 15 September 2021], demonstrated a synthetic lethality with acidosis even in 
the presence of lactate (Figure 9B). Interestingly, the effect of CPI-613 was accompanied by the increased rate of DCF oxidation, suggesting simultaneous induction of oxidative stress enforcing its toxicity (Figure 9C). The general validity of the CPI-613 effect was confirmed also for other cell lines including noncancerous HDF (Figure 9D-F). Finally, the combination of CPI-613 with tetracycline was synergistic in a two-week experiment with PaTu-8902 cells grown in conventional 2-D cultures (Figure 9G, Figure A8) and 3-D spheroids, previously reported to be enriched with oxidative cancer cells and cancer stem cells [45] (Figure A9).
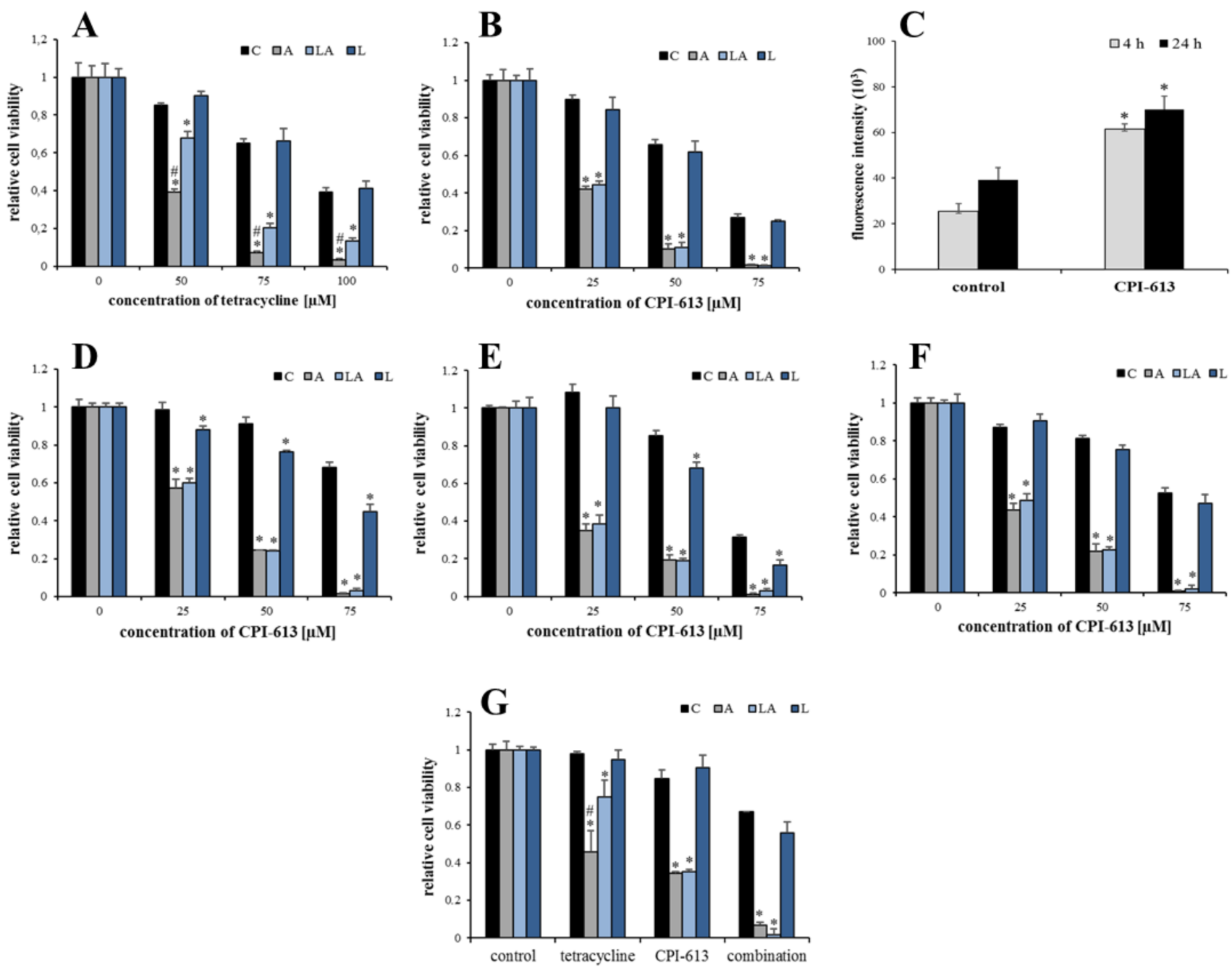

Figure 9. Inhibition of mitochondrial metabolism. PaTu-8902 cells were treated with the experimental media containing the indicated amount of (A) tetracycline or (B) CPI-613 for $72 \mathrm{~h}$, and the viability was measured. (C) Oxidation of $2^{\prime}, 7^{\prime}-$ dichlorodihydrofluorescein was measured as a relative fluorescence in PaTu-8902 treated with $50 \mu \mathrm{M}$ CPI-613 for 4 and 24 h. (D) HeLa, (E) HepG2, and (F) HDF cells were treated with the experimental media containing the indicated amount of CPI-613 for $72 \mathrm{~h}$, and the viability was measured. (G) PaTu-8902 cells were treated with experimental media containing $50 \mu \mathrm{M}$ CPI-613, $50 \mu \mathrm{M}$ tetracycline, or their combination for 2 weeks, and the viability was measured by resazurin assay. C, control; A, acidosis; LA, lactic acidosis; L, high lactate ( ${ }^{*} p<0.05$ compared to C, \# $p<0.05$ when comparing A and LA).

\section{Materials and Methods}

\subsection{Chemicals}

All reagents and media were purchased from Merck (Darmstadt, Germany) unless otherwise stated. Photosensitizers 5,10,15,20-tetrakis(4-isopropylphosphinatophenyl)porphyrin, herein abbreviated as TIPPP, and $\left[\mathrm{Mo}_{6} \mathrm{I}_{8}\left(\mathrm{OCOC}_{4} \mathrm{H}_{8} \mathrm{PPh}_{3}\right)_{6}\right] \mathrm{Br}_{4}$, abbreviated as Mo cluster, were a kind gift from Dr. Kaplan Kirakci and Dr. Kamil Lang, and their synthesis and 
characterization were described elsewhere [46,47]. The photosensitizing properties of pheophorbide $a$ were evaluated before [48]. None of these compounds showed dark toxicity at concentrations and incubation times used in this article. In general, photosensitizers, doxorubicin, tetracycline, and CPI-613 were dissolved in dimethyl sulfoxide (DMSO), and the aliquots were stored at $-20{ }^{\circ} \mathrm{C}$. Hydrogen peroxide, ascorbate, and carbonyl cyanide-4-(trifluoromethoxy)phenylhydrazone (FCCP) were dissolved in deionized water and immediately used.

\subsection{Cell Culture}

Human pancreatic adenocarcinoma PaTu-8902 cell line (DSMZ, Germany), human cervix carcinoma HeLa cell line, human hepatoblastoma Hep G2 cell line, and human dermal fibroblasts HDF (all ATCC, Manassas, VA, USA) were cultured in the Eagle's Minimum Essential Medium (EMEM) supplemented with $0.5 \mathrm{mM}$ glutamine and 5\% $(v / v)$ fetal bovine serum in $5 \% \mathrm{CO}_{2}$ atmosphere at $37^{\circ} \mathrm{C}$. Tumor spheroids were formed in Corning Elplasia 96-well plates (Corning, NY, USA).

\subsection{Experimental Media}

Four types of experimental media were used. The control (C) medium was EMEM supplemented with $0.5 \mathrm{mM}$ glutamine and $5 \%(v / v)$ fetal bovine serum. The high lactate (L) medium was enriched with $12 \mathrm{mM}$ sodium lactate. Both media have a physiological $\mathrm{pH}$ of 7.4 in the atmosphere with $5 \% \mathrm{CO}_{2}$. Acidosis (A) medium has adjusted $\mathrm{pH}$ to 6.8 with $12 \mathrm{mM}$ hydrochloric acid. Lactic acidosis (LA) medium was supplemented with $12 \mathrm{mM}$ lactic acid of final $\mathrm{pH}$ of 6.8 (Table 1 ).

Table 1. Experimental media.

\begin{tabular}{cccc}
\hline Name & Abbreviation & Lactate $[\mathrm{mM}]$ & $\mathbf{p H}$ \\
\hline Control & $\mathrm{C}$ & 0 & 7.4 \\
Acidosis & $\mathrm{A}$ & 0 & 6.8 \\
Lactic acidosis & LA & 12 & 6.8 \\
Lactate & L & 12 & 7.4 \\
\hline
\end{tabular}

\subsection{Cell Viability}

The cells were seeded in 96-well plates in a full cell culture medium at 20,000 cells per well. From the second day until the end of the experiment ( $72 \mathrm{~h}$ if not stated otherwise), the medium was replaced by the experimental media that were exchanged every $24 \mathrm{~h}$. The viability of the cells was measured with the resazurin assay $24 \mathrm{~h}$ after the challenge except for X-ray-irradiated and doxorubicin-treated cells that were measured after $72 \mathrm{~h}$. The X-ray irradiation was performed using X-RAD 225XL Biological irradiator (Precision X-ray, North Branford, CT, USA).

In the case of photosensitizers, cells were preincubated with the indicated concentrations of the compounds for $4 \mathrm{~h}$ (Mo cluster and pheophorbide $a$ ) or $24 \mathrm{~h}$ (TIPPP). The final concentration of DMSO in the medium was $1 \%(v / v)$ including controls. The cells treated with Mo cluster were illuminated with a $460 \mathrm{~nm}$ LED light (Cameo, $18 \mathrm{~mW} \cdot \mathrm{cm}^{-2}$ ), and the cells treated with pheophorbide $a$ or TIPPP were exposed to a $150 \mathrm{~W}$ halogen lamp equipped with a water filter (Thorlabs, $45 \mathrm{~mW} \cdot \mathrm{cm}^{-2}$ ) for $15 \mathrm{~min}$.

\subsection{Uptake and Intracellular Localization of the Photosensitizers}

The cells were treated with experimental media and photosensitizers as described for the viability measurement, but flow cytometry measurement or confocal microscopy were performed instead of light illumination.

Uptake was determined from ten thousand cells in triplicates using a BD FACSAria III flow cytometer (excitation $405 \mathrm{~nm}$, emission recorded at 655-685 nm), and the results were processed with the BD FACSDiva software (version 8, BD Biosciences, Franklin Lakes, NJ, USA). 
Confocal microscopy was performed with a spinning disc microscope (Revolution $\mathrm{xD}$, Andor, Oxford instruments, Abingdon, UK) operated with iQ3 software. The cells were washed and stained with LysoTracker ${ }^{\mathrm{TM}}$ Green DND-26 or MitoTracker ${ }^{\mathrm{TM}}$ Green (Thermo Fisher Scientific, Waltham, MA, USA). The excitation wavelengths used for monitoring the photosensitizers and lysosomes or mitochondria were 405 and $488 \mathrm{~nm}$, respectively. During the confocal microscopy, the cells were maintained at $37^{\circ} \mathrm{C}$ and $5 \% \mathrm{CO}_{2}$ atmosphere.

\subsection{Biochemical Assays}

The cells were seeded and treated as described for the viability measurement, but the following assays were performed instead of challenge:

ATP concentration was determined with an ATP assay kit from Abcam (Cambridge, UK, cat.: ab113849) according to the manufacturer's instructions.

NADPH concentrations were determined using NADP/NADPH quantification kit (cat.: MAK038) according to the manufacturer's instructions.

Production of ROS in the cells was determined by detection of fluorescent intensity of dihydroethidium $(10 \mathrm{mM})$ and $2^{\prime}, 7^{\prime}$-dichlorofluorescein diacetate $(10 \mu \mathrm{M})$ by flow cytometry or fluorescent detector SpectraMax i3 Platform (Molecular Devices, San Jose, CA, USA).

Relative oxygen consumption was determined by the Oxygraph+ system from Hansatech instruments (Pentney, UK). One $\mathrm{mL}$ of experimental media with $10^{8}$ cells was used for the measurement.

The total antioxidant capacity of the cell pellet was determined after resuspending in $250 \mu \mathrm{L}$ of distilled water and $500 \mu \mathrm{L}$ of dipyridamole $(2.5 \mathrm{mM})$. Next, $80 \mu \mathrm{L}$ of the sample was mixed with $20 \mu \mathrm{L}$ of 2,2'-azobis(2-methylpropionamidine) dihydrochloride $(25 \mathrm{mM})$ in a 96-well plate. The decrease of dipyridamole fluorescence due to oxidation was continuously monitored at $480 \mathrm{~nm}$ with $415 \mathrm{~nm}$ excitation and compared with Trolox as a standard.

\subsection{Glutathione}

Samples were extracted by $50 \mu \mathrm{L}$ of $20 \mathrm{mM}$ iodoacetamide solution in ammonium bicarbonate buffer by vortexing and incubating for $10 \mathrm{~min}$ at $4{ }^{\circ} \mathrm{C}$. Then, the samples were deproteinized with $200 \mu \mathrm{L}$ of acetonitrile/methanol mixture $(1: 1, v / v)$ and centrifuged for $10 \mathrm{~min}$. The supernatants were injected onto ACQUITY UPLC BEH Amide $(100 \times 2.1 \mathrm{~mm}$, $1.7 \mu \mathrm{m}$, Waters Corporation, Milford, MA, USA) column. The analysis was conducted by TSQ Quantum Access Max mass spectrometry (Thermo Fisher Scientific) in positive ionization SRM mode. The MS/MS parameters were optimized by standards through direct infusion. The selected reaction monitoring parameters are shown in Table 2. The MS detector equipped with a HESI-II probe was run under the following conditions: vaporizer temperature of $320^{\circ} \mathrm{C}$, spray voltage of $+2250 \mathrm{~V}$, sheath gas pressure of 34 arbitrary units (AU), the auxiliary gas pressure of $15 \mathrm{AU}$, ion sweep gas pressure of $11.2 \mathrm{AU}$, collision gas (Ar) pressure of $1.0 \mathrm{mTorr}$, and capillary temperature of $320^{\circ} \mathrm{C}$. The skimmer offset voltage was $10 \mathrm{~V}$. The peaks were integrated with the Thermo Xcalibur software (Thermo Fisher Scientific).

Table 2. Selected reaction monitoring parameters for the glutathione determination.

\begin{tabular}{ccccc}
\hline Metabolite & Parent Ion & Product Ion & Collision Energy & Tube Lens Voltage \\
\hline GSH & 365.1 & 236.2 & $13 \mathrm{~V}, 20 \mathrm{~V}$ & $93.65 \mathrm{~V}$ \\
GSSG & 613.2 & 355.1 & $24 \mathrm{~V}, 40 \mathrm{~V}$ & 122 \\
\hline
\end{tabular}

\subsection{Glucose and Lactate in Media}

Analysis of lactate and glucose was performed by gas chromatography/mass spectrometry (Agilent Technologies, Santa Clara, CA, USA, GC7890/MS5975) in electron impact mode. Samples for the determination of lactate were extracted with a mixture of methanol, 
water, and chloroform (1:1:2, $v / v / v)$ after the addition of the internal standard of sodium oxalate. After centrifugation at $1000 \times g$ for $10 \mathrm{~min}$., the upper polar phase was transferred into a clean vial and lyophilized overnight. The samples were derivatized with the mixture of pyridine, $\mathrm{N}, \mathrm{O}$-bis (trimethyl)silylacetamide, and chlorotrimethylsilane (4:2:1, v/v/v). After $90 \mathrm{~min}$ at $65^{\circ} \mathrm{C}$, the mixture was injected onto an HP-5MS capillary column.

Samples for the glucose determination were diluted with methanol after the addition of the internal standard D-glucose- ${ }^{13} \mathrm{C}_{6}$. After centrifugation at $5000 \times g$ for $5 \mathrm{~min}$, the supernatant was transferred into a clean vial. The samples were derivatized with hydroxylamine hydrochloride in pyridine ( $2 \mathrm{mg}$ in $150 \mu \mathrm{L}$ of pyridine). After $30 \mathrm{~min}$ at $90{ }^{\circ} \mathrm{C}$, acetic anhydride was added to the mixture. After another $30 \mathrm{~min}$ at $90{ }^{\circ} \mathrm{C}$, the samples were dried out under the nitrogen and dissolved in $500 \mu \mathrm{L}$ of chloroform before injection onto the column. The retention times and characteristic $m / z$ of analyzed metabolites are attached in Table 3.

Table 3. Retention times and characteristic mass/charge of analyzed metabolites.

\begin{tabular}{ccc}
\hline Metabolite & $m / z$ & Retention Time [min] \\
\hline Oxalate (IS) & 190 & 2.15 \\
Lactate & 219 & $1.63+4.89$ \\
Glucose & 314.3 & 4.53 \\
Glucose- ${ }^{13} \mathrm{C}_{6}$ (IS) & 319.3 & 4.53 \\
\hline
\end{tabular}

\subsection{Statistical Analysis}

Statistica software was used to assess the statistical significance of the data. Statistical differences were evaluated by one-way ANOVA followed by Duncan's post-hoc test. Significance was set at $p<0.05\left(^{*} p<0.05\right.$ compared to $C_{1}{ }^{*} p<0.05$ when comparing A and LA). The data were expressed as mean \pm standard deviation.

\section{Conclusions}

The acidity of the tumor microenvironment has been linked to immune escape, increased invasiveness, and a worse prognosis of cancer patients. Therefore, neutralization of tumor extracellular $\mathrm{pH}$ is considered a promising therapeutic goal. This study presents acidosis as the Achilles' heel of cancer. Acidosis significantly sensitized cells to hydrogen peroxide, cytotoxic doses of ascorbate, and photodynamic therapy with several photosensitizers. This effect was caused by the depletion of antioxidant capacity caused by an insufficient supply of NADPH. However, the sensitization was significantly ameliorated in the presence of respiratory substrate lactate. Inhibition of the Krebs cycle with CPI-613 resulted in selective killing of the cells adapted to acidosis even in the presence of lactate. This effect was further enhanced by tetracycline and confirmed also in tumor spheroids. In conclusion, CPI-613 and its combination with antibiotics inhibiting mitochondrial proteosynthesis could serve for selective eradication of acidosis-adapted cells, possibly improving the success rate of anticancer therapy and patient prognosis.

Author Contributions: Conceptualization, J.Z.; methodology, M.K., N.V., I.K., P.T., S.R.; formal analysis, J.Z., A.D., M.R., L.V., S.R., T.R.; resources, T.R., L.V.; writing-original draft preparation, M.K., J.Z.; writing—review and editing, ALL; visualization, M.K., N.V., S.R., J.Z.; supervision, J.Z., A.D., L.V., M.R., T.R.; funding acquisition, T.R. All authors have read and agreed to the published version of the manuscript.

Funding: This work was supported by grant no. 21-11688S was given by the Czech Science Foundation.

Institutional Review Board Statement: Not applicable.

Informed Consent Statement: Not applicable.

Acknowledgments: The authors thank Zuzana Lenertová and Eliška Malíková for the work with cell cultures and Kaplan Kirakci and Kamil Lang for providing us with the Mo cluster and TIPPP. 
Conflicts of Interest: The authors declare no conflict of interest.

\section{Abbreviations}

$\begin{array}{ll}\text { ATP } & \text { Adenosine triphosphate } \\ \text { AU } & \text { Arbitrary units } \\ \text { CAIX } & \text { Carbonic anhydrase IX } \\ \text { CAXII } & \text { Carbonic anhydrase XII } \\ \text { DCF } & 2^{\prime}, 7^{\prime} \text {-dichlorodihydrofluorescein } \\ \text { DMSO } & \text { Dimethyl sulfoxide } \\ \text { DNA } & \text { Deoxyribonucleic acid } \\ \text { EMEM } & \text { Eagle's Minimum Essential Medium } \\ \text { FCCP } & \text { Carbonyl cyanide-p-trifluoromethoxyphenylhydrazone } \\ \text { HDF } & \text { Human dermal fibroblasts } \\ \text { HeLa } & \text { Human cells from cervical carcinoma } \\ \text { Hep G2 } & \text { Human cells from hepatocarcinoma } \\ \text { LA } & \text { Lactic acidosis } \\ \text { NADPH } & \text { Nicotinamide adenine dinucleotide phosphate } \\ \text { NNT } & \text { Nicotinamide nucleotide transhydrogenase } \\ \text { PaTu-8902 } & \text { Human cells from pancreatic carcinoma } \\ \text { PDT } & \text { Photodynamic therapy } \\ \text { ROS } & \text { Reactive oxygen species } \\ \text { TIPPP } & \text { 5,10,15,20-tetrakis(4-isopropylphosphinatophenyl)porphyrin }\end{array}$

\section{Appendix A}

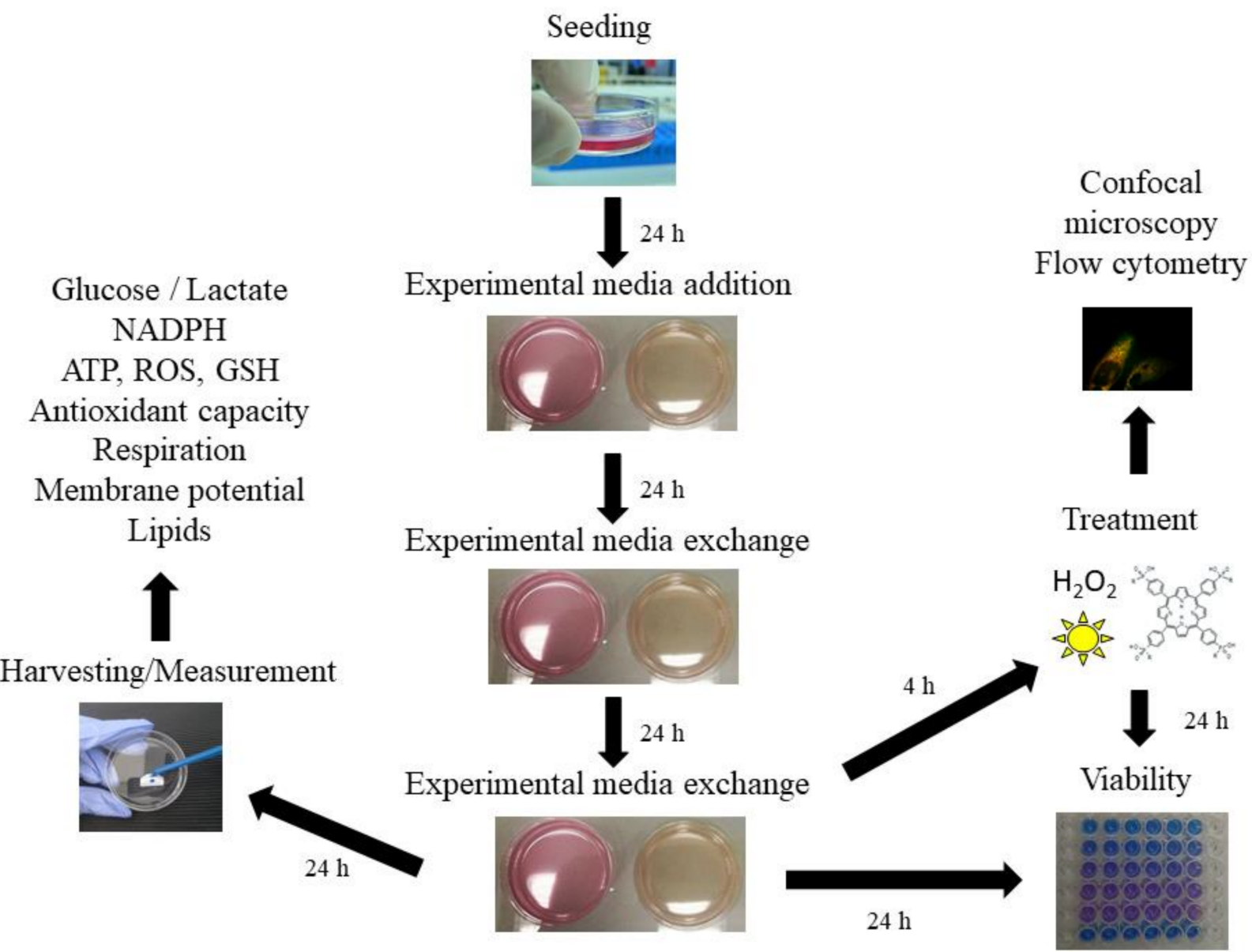

Figure A1. The summary of the cell treatment with experimental media and subsequent measurements. 

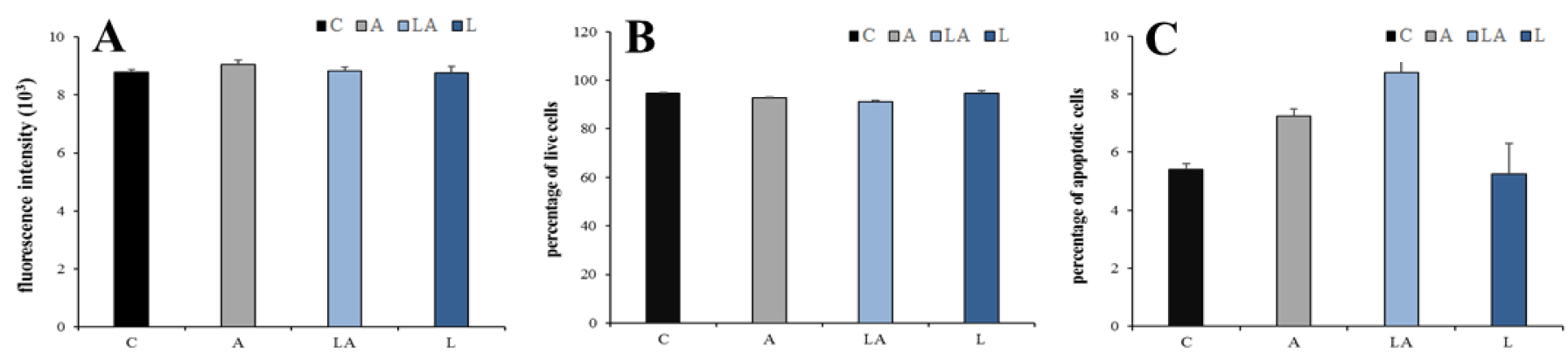

Figure A2. The effect of lactic acidosis on cancer cell viability. Viability (A) of PaTu-8902 cells cultured in experimental media for $72 \mathrm{~h}$. Percentage of living (B) and apoptotic (C) cells in the cell population cultured in experimental media for $72 \mathrm{~h}$. Viability was measured by resazurin assay. Apoptosis was determined using flow cytometry. C, control; A, acidosis; LA, lactic acidosis; L, high lactate.

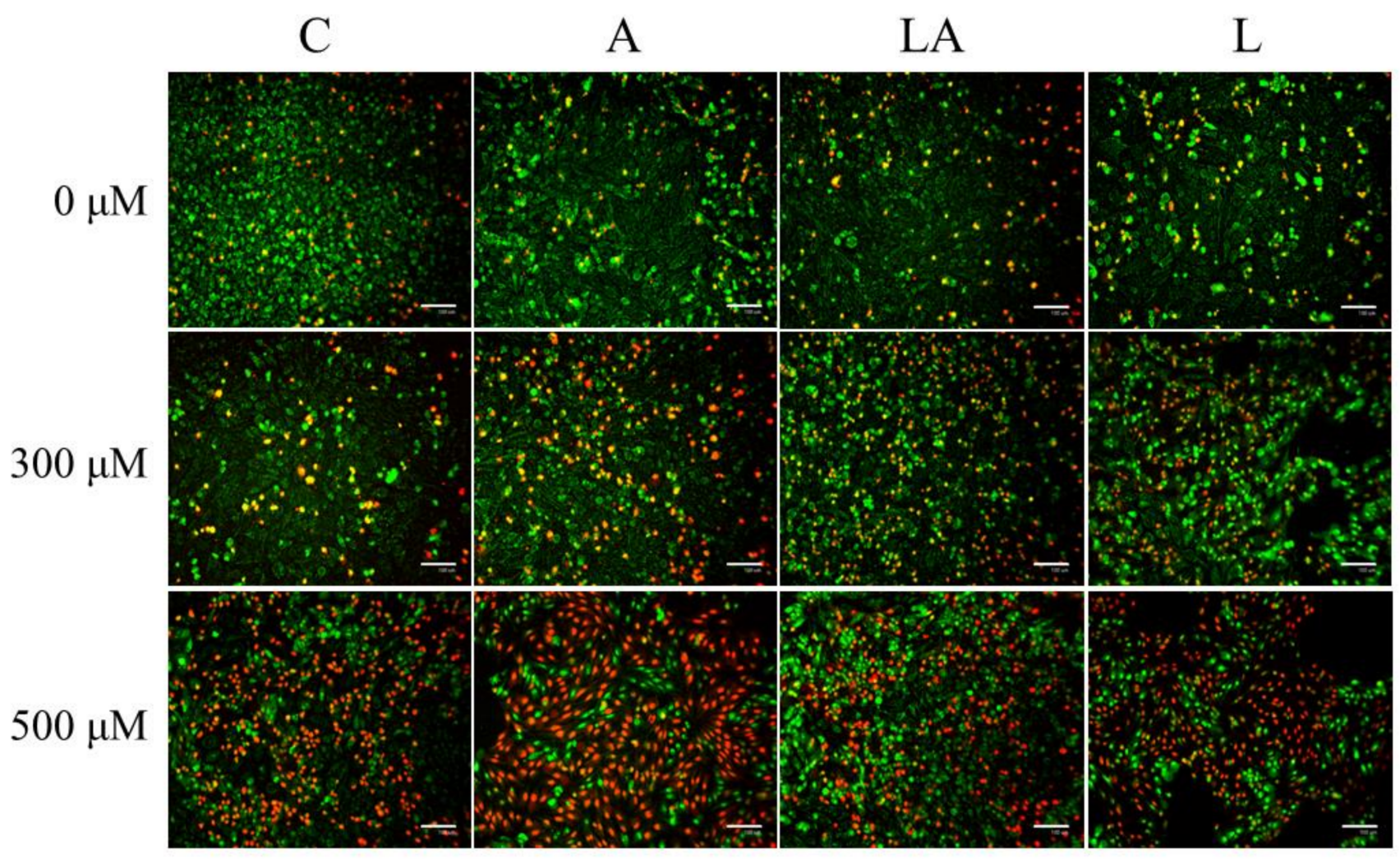

Figure A3. Live/dead staining of the cells treated with hydrogen peroxide. HeLa cells were cultured in experimental media for $72 \mathrm{~h}$ and treated with indicated concentrations of hydrogen peroxide. Total cells were stained with SYTO-9 (green), dead cells were stained with propidium iodide (red). C, control; A, acidosis; LA, lactic acidosis; L, high lactate. 

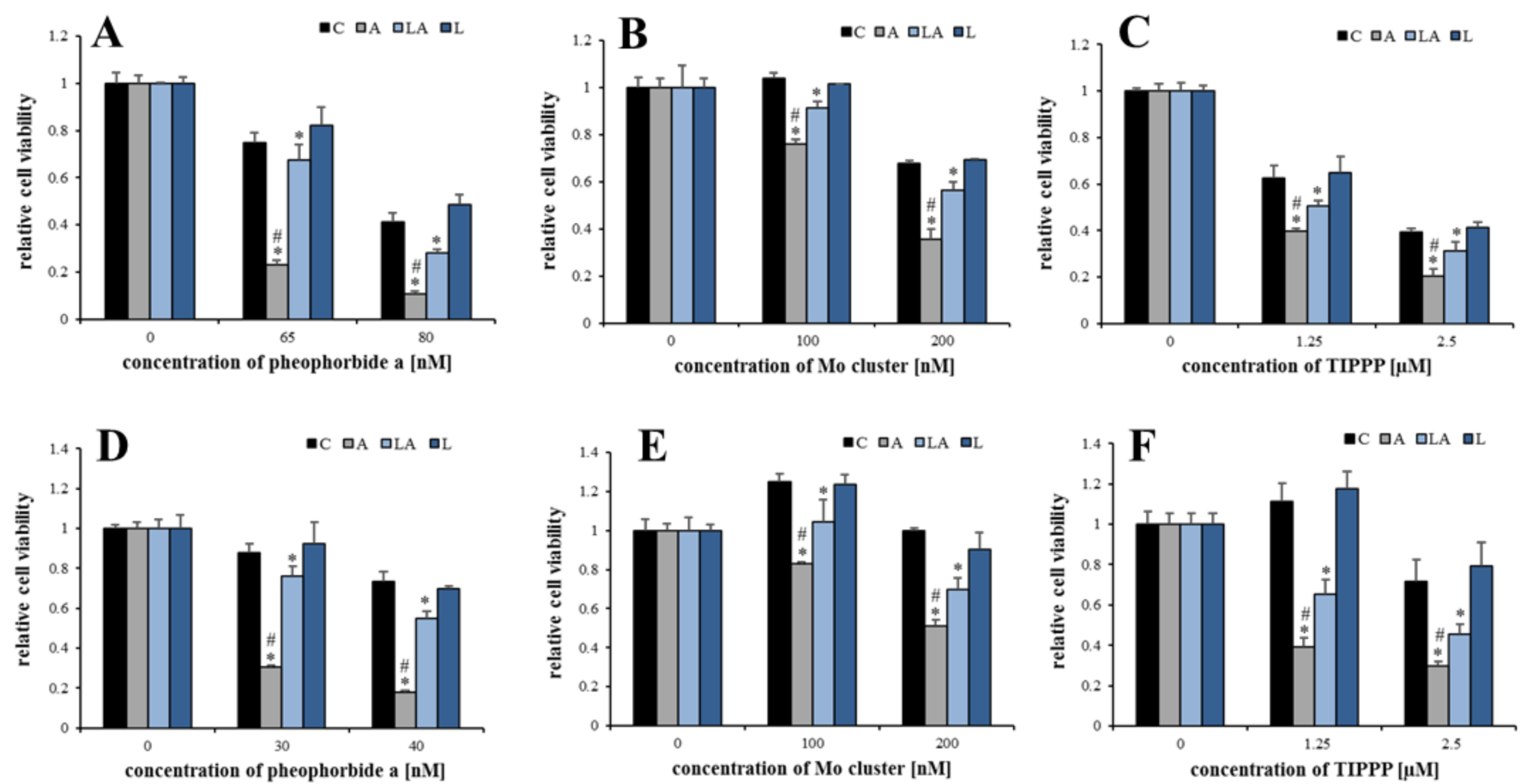

Figure A4. The effect of lactic acidosis on cancer cell sensitivity to photodynamic therapy. Viability of HeLa (A-C) and Hep G2 (D-F) cells cultured in experimental media for $72 \mathrm{~h}$ and then treated with photodynamic therapy using (A,D) pheophorbide $a$, (B,E) Mo cluster, and (C,F) 5,10,15,20-tetrakis(4-isopropylphosphinatophenyl)porphyrin (TIPPP). Viability was measured by resazurin assay. C, control; A, acidosis; LA, lactic acidosis; L, high lactate $\left({ }^{*} p<0.05\right.$ compared to C, $\# p<0.05$ when comparing A and LA).

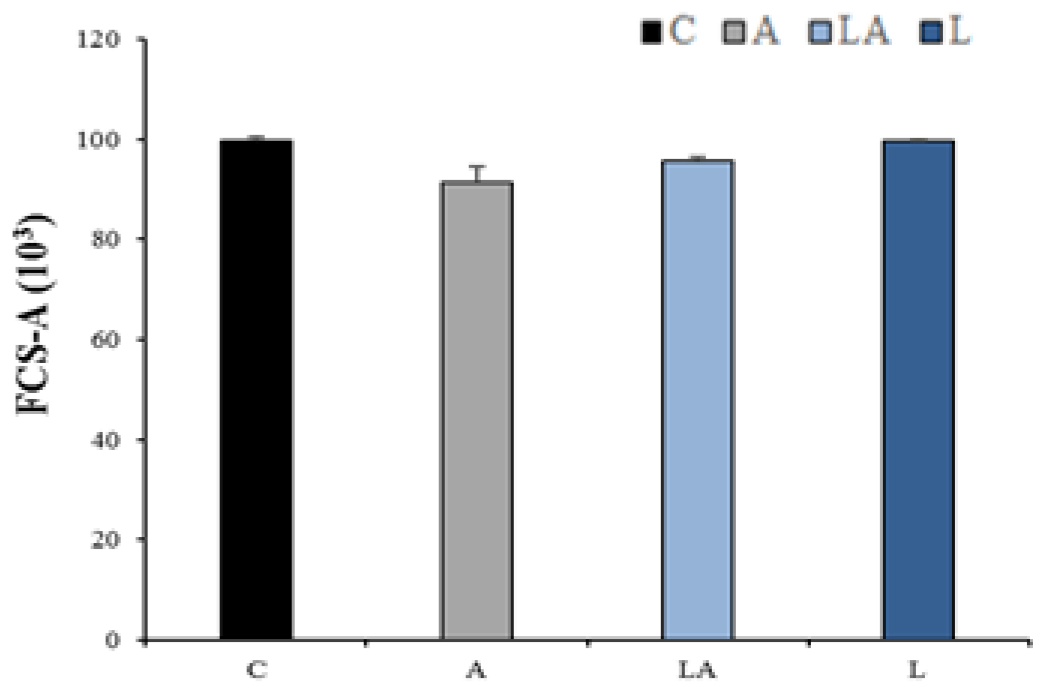

Figure A5. The cell size. Measured as a forward scatter of flow cytometry of PaTu-8902 cells treated with experimental media for $72 \mathrm{~h}$. C, control; A, acidosis; LA, lactic acidosis; L, high lactate. 


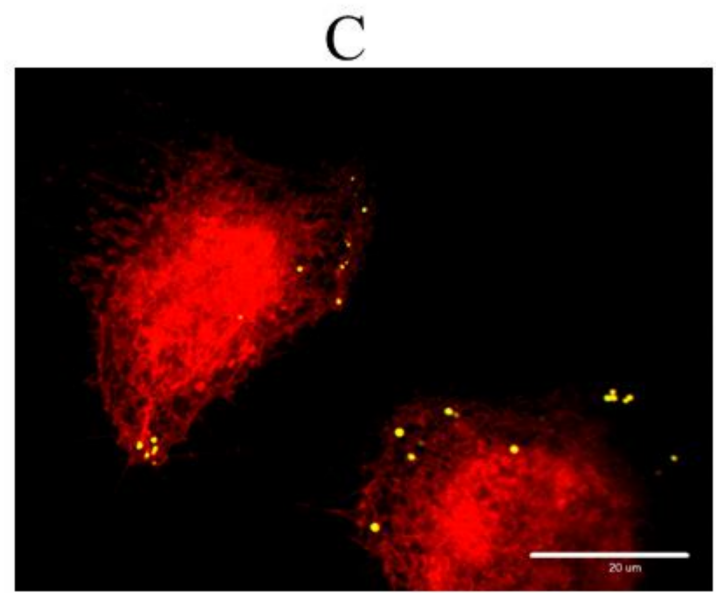

LA

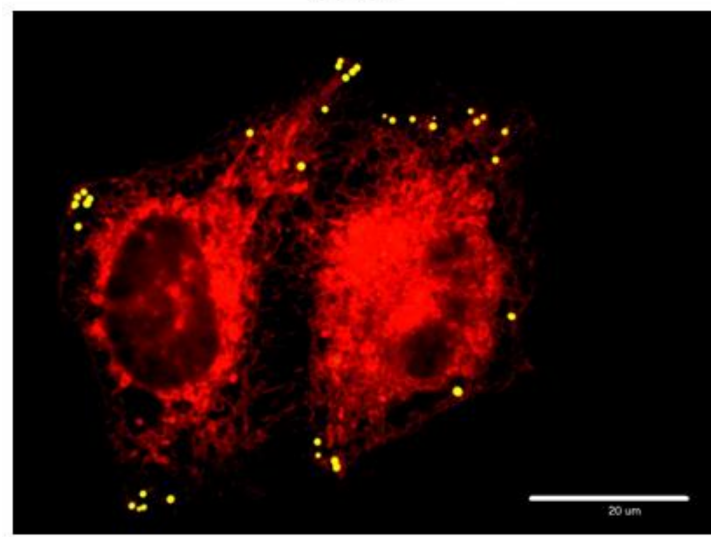

A

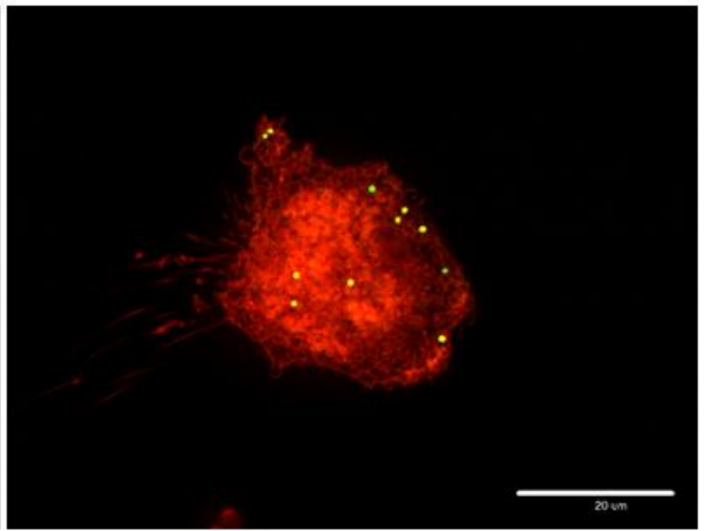

$\mathrm{L}$

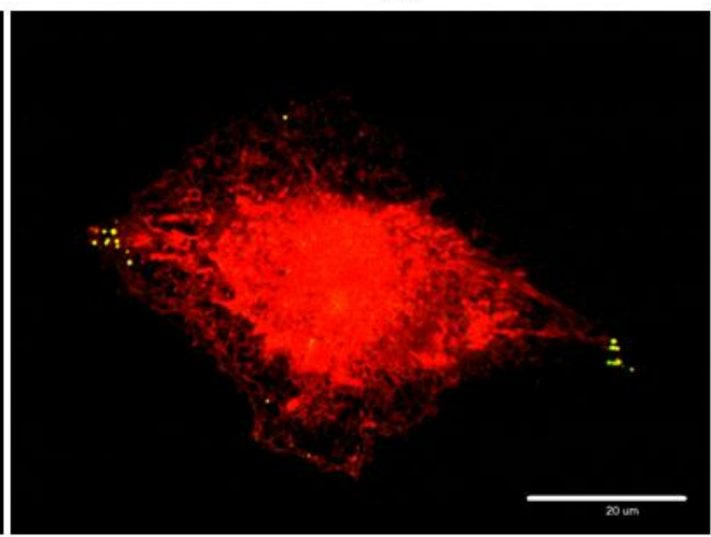

Figure A6. Representative images of HeLa cells stained with Nile red. HeLa cells were treated with the experimental media for $72 \mathrm{~h}$, stained with Nile red, and inspected with confocal microscopy. Yellow fluorescence signal (488/525 nm) corresponds to droplets of neutral lipids and red signal $(560 / 610 \mathrm{~nm})$ corresponds to phospholipid membranes. C, control; A, acidosis; LA, lactic acidosis; L, high lactate.

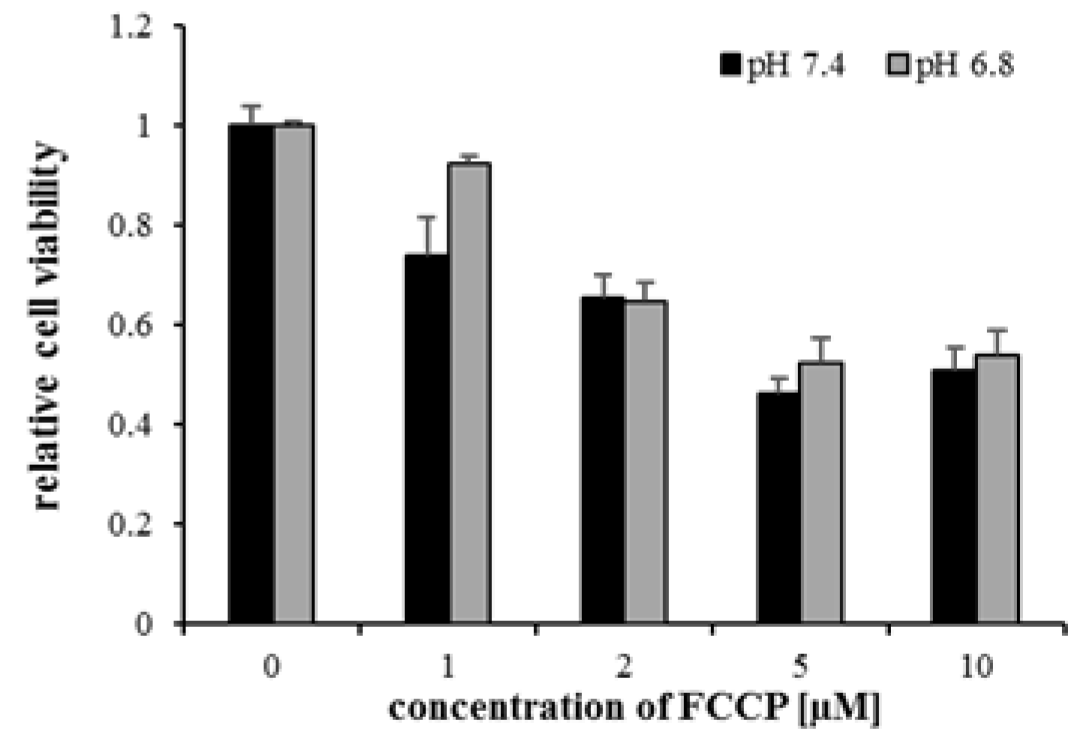

Figure A7. The effect of $\mathrm{pH}$ on cancer cell sensitivity to carbonyl cyanide- $p$-trifluoromethoxy phenylhydrazone (FCCP). Viability of PaTu-8902 cells cultured in media with different $\mathrm{pH}$ for $72 \mathrm{~h}$ and with FCCP for $24 \mathrm{~h}$. Viability was measured by resazurin assay. 


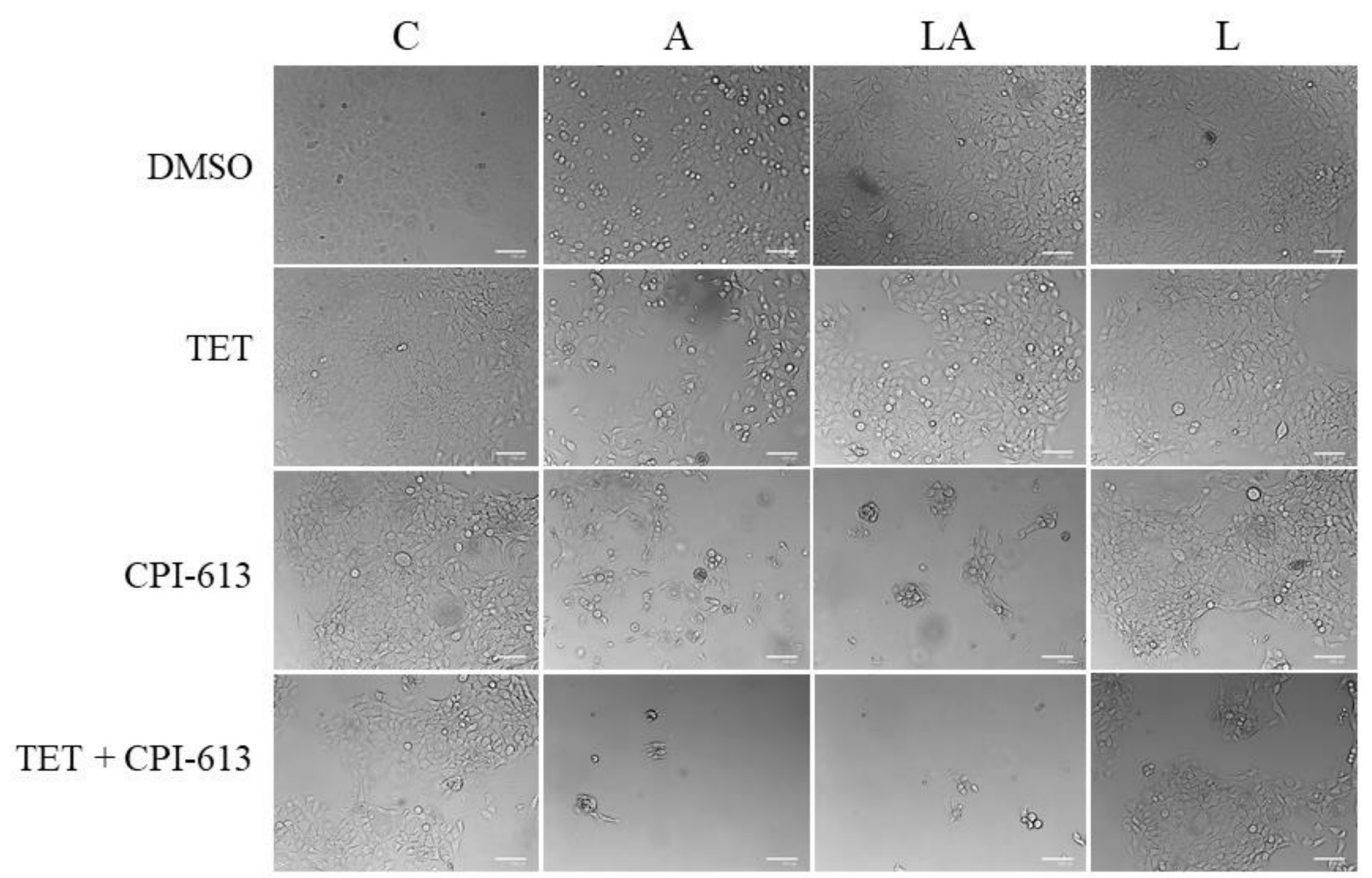

Figure A8. Representative images of 2D cultures treated with CPI-613 and tetracycline for 2 weeks. PaTu-8902 cells were cultured for 2 weeks in the presence of $1 \%$ dimethyl sulfoxide as a vehicle (DMSO), $50 \mu \mathrm{M}$ tetracycline (TET), $50 \mu \mathrm{M}$ CPI-613, or both.

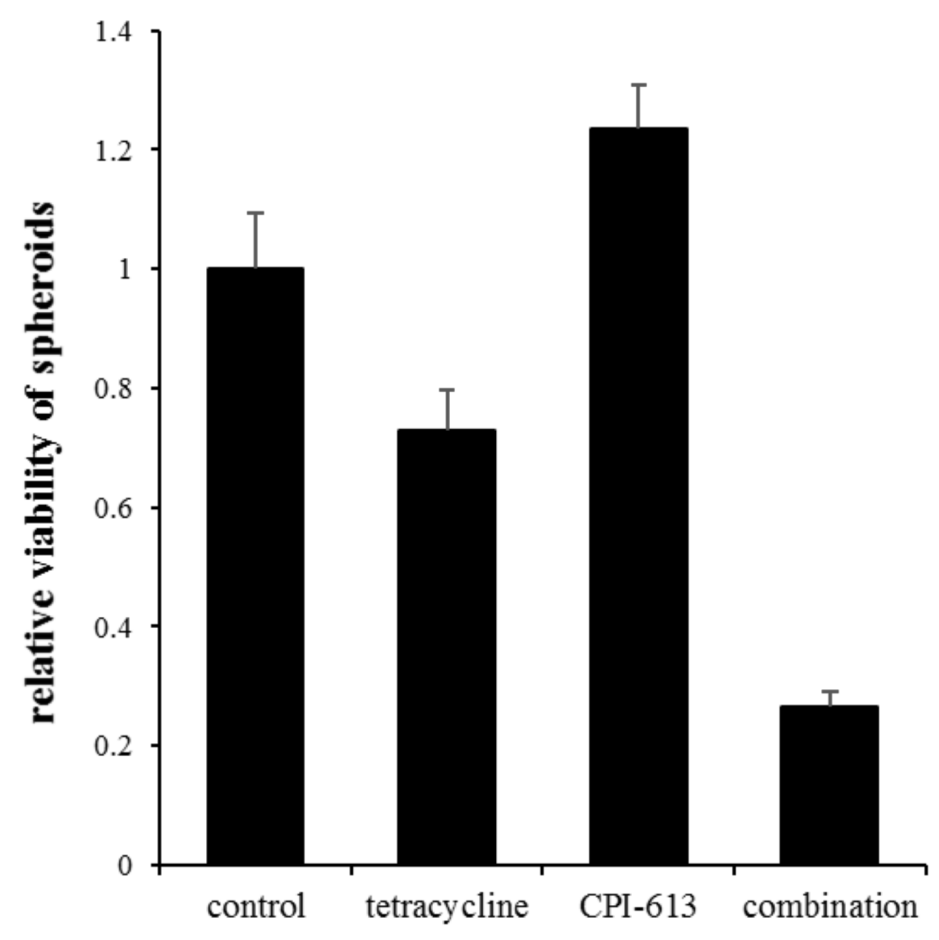

Figure A9. The effect of CPI-613 and tetracycline on the viability of spheroids. Viability of PaTu8902 cells cultured in the form of spheroids for 2 weeks in the presence of $1 \%$ dimethyl sulfoxide as a vehicle (control), $50 \mu \mathrm{M}$ tetracycline, $50 \mu \mathrm{M}$ CPI-613, or both. Viability was measured by resazurin assay. 


\section{References}

1. Liberti, M.V.; Locasale, J.W. The warburg effect: How does it benefit cancer cells? Trends Biochem. Sci. 2016, 41, 211-218. [CrossRef] [PubMed]

2. Becker, H.M. Carbonic anhydrase ix and acid transport in cancer. Br. J. Cancer 2020, 122, 157-167. [CrossRef]

3. Martinez-Outschoorn, U.E.; Peiris-Pagés, M.; Pestell, R.G.; Sotgia, F.; Lisanti, M.P. Cancer metabolism: A therapeutic perspective. Nat. Rev. Clin. Oncol. 2017, 14,11-31. [CrossRef]

4. Roland, C.L.; Arumugam, T.; Deng, D.; Liu, S.H.; Philip, B.; Gomez, S.; Burns, W.R.; Ramachandran, V.; Wang, H.; CruzMonserrate, Z.; et al. Cell surface lactate receptor gpr81 is crucial for cancer cell survival. Cancer Res. 2014, 74, 5301-5310. [CrossRef]

5. $\quad$ LeBleu, V.S.; O’Connell, J.T.; Gonzalez Herrera, K.N.; Wikman, H.; Pantel, K.; Haigis, M.C.; de Carvalho, F.M.; Damascena, A.; Domingos Chinen, L.T.; Rocha, R.M.; et al. Pgc- $1 \alpha$ mediates mitochondrial biogenesis and oxidative phosphorylation in cancer cells to promote metastasis. Nat. Cell Biol. 2014, 16, 992-1003. [CrossRef] [PubMed]

6. Blatt, S.; Voelxen, N.; Sagheb, K.; Pabst, A.M.; Walenta, S.; Schroeder, T.; Mueller-Klieser, W.; Ziebart, T. Lactate as a predictive marker for tumor recurrence in patients with head and neck squamous cell carcinoma (hnscc) post radiation: A prospective study over 15 years. Clin. Oral Investig. 2016, 20, 2097-2104. [CrossRef] [PubMed]

7. Walenta, S.; Wetterling, M.; Lehrke, M.; Schwickert, G.; Sundfør, K.; Rofstad, E.K.; Mueller-Klieser, W. High lactate levels predict likelihood of metastases, tumor recurrence, and restricted patient survival in human cervical cancers. Cancer Res. 2000, 60, 916-921.

8. Thews, O.; Riemann, A. Tumor ph and metastasis: A malignant process beyond hypoxia. Cancer Metastasis Rev. 2019, 38, 113-129. [CrossRef]

9. Robey, I.F.; Baggett, B.K.; Kirkpatrick, N.D.; Roe, D.J.; Dosescu, J.; Sloane, B.F.; Hashim, A.I.; Morse, D.L.; Raghunand, N.; Gatenby, R.A.; et al. Bicarbonate increases tumor ph and inhibits spontaneous metastases. J. Cancer Res. 2009, 69, 2260-2268. [CrossRef]

10. Gottfried, E.; Kunz-Schughart, L.A.; Ebner, S.; Mueller-Klieser, W.; Hoves, S.; Andreesen, R.; Mackensen, A.; Kreutz, M. Tumor-derived lactic acid modulates dendritic cell activation and antigen expression. Blood 2006, 107, 2013-2021. [CrossRef]

11. Colegio, O.R.; Chu, N.Q.; Szabo, A.L.; Chu, T.; Rhebergen, A.M.; Jairam, V.; Cyrus, N.; Brokowski, C.E.; Eisenbarth, S.C.; Phillips, G.M.; et al. Functional polarization of tumour-associated macrophages by tumour-derived lactic acid. Nature 2014, 513, 559-563. [CrossRef]

12. Lee, D.C.; Sohn, H.A.; Park, Z.Y.; Oh, S.; Kang, Y.K.; Lee, K.M.; Kang, M.; Jang, Y.J.; Yang, S.J.; Hong, Y.K.; et al. A lactate-induced response to hypoxia. Cell 2015, 161, 595-609. [CrossRef]

13. McDonald, P.C.; Chia, S.; Bedard, P.L.; Chu, Q.; Lyle, M.; Tang, L.; Singh, M.; Zhang, Z.; Supuran, C.T.; Renouf, D.J.; et al. A phase 1 study of slc-0111, a novel inhibitor of carbonic anhydrase ix, in patients with advanced solid tumors. Am. J. Clin. Oncol. 2020, 43, 484-490. [CrossRef]

14. Lou, Y.; McDonald, P.C.; Oloumi, A.; Chia, S.; Ostlund, C.; Ahmadi, A.; Kyle, A.; Auf dem Keller, U.; Leung, S.; Huntsman, D.; et al. Targeting tumor hypoxia: Suppression of breast tumor growth and metastasis by novel carbonic anhydrase ix inhibitors. Cancer Res. 2011, 71, 3364-3376. [CrossRef]

15. Le, A.; Cooper, C.R.; Gouw, A.M.; Dinavahi, R.; Maitra, A.; Deck, L.M.; Royer, R.E.; Vander Jagt, D.L.; Semenza, G.L.; Dang, C.V. Inhibition of lactate dehydrogenase a induces oxidative stress and inhibits tumor progression. Proc. Natl. Acad. Sci. USA 2010, 107, 2037-2042. [CrossRef] [PubMed]

16. Xie, H.; Hanai, J.; Ren, J.G.; Kats, L.; Burgess, K.; Bhargava, P.; Signoretti, S.; Billiard, J.; Duffy, K.J.; Grant, A.; et al. Targeting lactate dehydrogenase-a inhibits tumorigenesis and tumor progression in mouse models of lung cancer and impacts tumor-initiating cells. Cell Metab. 2014, 19, 795-809. [CrossRef] [PubMed]

17. Doherty, J.R.; Cleveland, J.L. Targeting lactate metabolism for cancer therapeutics. J. Clin. Investig. 2013, 123, 3685-3692. [CrossRef]

18. Bola, B.M.; Chadwick, A.L.; Michopoulos, F.; Blount, K.G.; Telfer, B.A.; Williams, K.J.; Smith, P.D.; Critchlow, S.E.; Stratford, I.J. Inhibition of monocarboxylate transporter-1 (mct1) by azd3965 enhances radiosensitivity by reducing lactate transport. Mol. Cancer Ther. 2014, 13, 2805-2816. [CrossRef]

19. Kuo, T.C.; Huang, K.Y.; Yang, S.C.; Wu, S.; Chung, W.C.; Chang, Y.L.; Hong, T.M.; Wang, S.P.; Chen, H.Y.; Hsiao, T.H.; et al. Monocarboxylate transporter 4 is a therapeutic target in non-small cell lung cancer with aerobic glycolysis preference. Mol. Ther. Oncolytics 2020, 18, 189-201. [CrossRef] [PubMed]

20. Gorrini, C.; Harris, I.S.; Mak, T.W. Modulation of oxidative stress as an anticancer strategy. Nat. Rev. Drug Discov. 2013, 12, 931-947. [CrossRef]

21. Zelenka, J.; Koncošová, M.; Ruml, T. Targeting of stress response pathways in the prevention and treatment of cancer. Biotechnol. Adv. 2018, 36, 583-602. [CrossRef]

22. Piskounova, E.; Agathocleous, M.; Murphy, M.M.; Hu, Z.; Huddlestun, S.E.; Zhao, Z.; Leitch, A.M.; Johnson, T.M.; DeBerardinis, R.J.; Morrison, S.J. Oxidative stress inhibits distant metastasis by human melanoma cells. Nature 2015, 527, 186-191. [CrossRef]

23. Sayin, V.I.; Ibrahim, M.X.; Larsson, E.; Nilsson, J.A.; Lindahl, P.; Bergo, M.O. Antioxidants accelerate lung cancer progression in mice. Sci. Transl. Med. 2014, 6, 221ra215. [CrossRef] 
24. Lopes-Coelho, F.; Gouveia-Fernandes, S.; Gonçalves, L.G.; Nunes, C.; Faustino, I.; Silva, F.; Félix, A.; Pereira, S.A.; Serpa, J. Hnf1 $\beta$ drives glutathione (gsh) synthesis underlying intrinsic carboplatin resistance of ovarian clear cell carcinoma (occc). Tumour Biol. J. Int. Soc. Oncodevelopmental Biol. Med. 2016, 37, 4813-4829. [CrossRef]

25. Hammad, A.; Namani, A.; Elshaer, M.; Wang, X.J.; Tang, X. "Nrf2 addiction" in lung cancer cells and its impact on cancer therapy. Cancer Lett. 2019, 467, 40-49. [CrossRef]

26. Zelenka, J.; Dvořák, A.; Alán, L. L-lactate protects skin fibroblasts against aging-associated mitochondrial dysfunction via mitohormesis. Oxidative Med. Cell. Longev. 2015, 2015, 351698. [CrossRef]

27. Zhao, M.; Liu, Q.; Gong, Y.; Xu, X.; Zhang, C.; Liu, X.; Zhang, C.; Guo, H.; Zhang, X.; Gong, Y.; et al. Gsh-dependent antioxidant defense contributes to the acclimation of colon cancer cells to acidic microenvironment. Cell Cycle 2016, 15, 1125-1133. [CrossRef]

28. Lamonte, G.; Tang, X.; Chen, J.L.; Wu, J.; Ding, C.K.; Keenan, M.M.; Sangokoya, C.; Kung, H.N.; Ilkayeva, O.; Boros, L.G.; et al. Acidosis induces reprogramming of cellular metabolism to mitigate oxidative stress. Cancer Metab. 2013, 1, 23. [CrossRef]

29. Gao, J.; Guo, Z.; Cheng, J.; Sun, B.; Yang, J.; Li, H.; Wu, S.; Dong, F.; Yan, X. Differential metabolic responses in breast cancer cell lines to acidosis and lactic acidosis revealed by stable isotope assisted metabolomics. Sci. Rep. 2020, 10, 21967. [CrossRef]

30. Hashimoto, T.; Hussien, R.; Oommen, S.; Gohil, K.; Brooks, G.A. Lactate sensitive transcription factor network in 16 cells: Activation of mct1 and mitochondrial biogenesis. FASEB J. Off. Publ. Fed. Am. Soc. Exp. Biol. 2007, 21, 2602-2612. [CrossRef]

31. Tauffenberger, A.; Fiumelli, H.; Almustafa, S.; Magistretti, P.J. Lactate and pyruvate promote oxidative stress resistance through hormetic ros signaling. Cell Death Dis. 2019, 10, 653. [CrossRef]

32. Abrego, J.; Gunda, V.; Vernucci, E.; Shukla, S.K.; King, R.J.; Dasgupta, A.; Goode, G.; Murthy, D.; Yu, F.; Singh, P.K. Got1-mediated anaplerotic glutamine metabolism regulates chronic acidosis stress in pancreatic cancer cells. Cancer Lett. 2017, 400, 37-46. [CrossRef]

33. Porporato, P.E.; Payen, V.L.; De Saedeleer, C.J.; Préat, V.; Thissen, J.P.; Feron, O.; Sonveaux, P. Lactate stimulates angiogenesis and accelerates the healing of superficial and ischemic wounds in mice. Angiogenesis 2012, 15, 581-592. [CrossRef]

34. Yang, L.; Hu, X.; Mo, Y.Y. Acidosis promotes tumorigenesis by activating akt/nf-kb signaling. Cancer Metastasis Rev. 2019, 38, 179-188. [CrossRef]

35. Schoenfeld, J.D.; Alexander, M.S.; Waldron, T.J.; Sibenaller, Z.A.; Spitz, D.R.; Buettner, G.R.; Allen, B.G.; Cullen, J.J. Pharmacological ascorbate as a means of sensitizing cancer cells to radio-chemotherapy while protecting normal tissue. Semin. Radiat. Oncol. 2019, 29, 25-32. [CrossRef]

36. Ying, W. Nad $+/$ nadh and nadp $+/$ nadph in cellular functions and cell death: Regulation and biological consequences. Antioxid. Redox Signal. 2008, 10, 179-206. [CrossRef]

37. Chen, X.; Zhong, Z.; Xu, Z.; Chen, L.; Wang, Y. $2^{\prime}, 7^{\prime}$-dichlorodihydrofluorescein as a fluorescent probe for reactive oxygen species measurement: Forty years of application and controversy. Free Radic. Res. 2010, 44, 587-604. [CrossRef]

38. Corbet, C.; Bastien, E.; Santiago de Jesus, J.P.; Dierge, E.; Martherus, R.; Vander Linden, C.; Doix, B.; Degavre, C.; Guilbaud, C.; Petit, L.; et al. Tgf $\beta 2$-induced formation of lipid droplets supports acidosis-driven emt and the metastatic spreading of cancer cells. Nat. Commun. 2020, 11, 454. [CrossRef]

39. Corbet, C.; Pinto, A.; Martherus, R.; Santiago de Jesus, J.P.; Polet, F.; Feron, O. Acidosis drives the reprogramming of fatty acid metabolism in cancer cells through changes in mitochondrial and histone acetylation. Cell Metab. 2016, 24, 311-323. [CrossRef]

40. Pérez-Escuredo, J.; Dadhich, R.K.; Dhup, S.; Cacace, A.; Van Hée, V.F.; De Saedeleer, C.J.; Sboarina, M.; Rodriguez, F.; Fontenille, M.J.; Brisson, L.; et al. Lactate promotes glutamine uptake and metabolism in oxidative cancer cells. Cell Cycle 2016, 15, 72-83. [CrossRef]

41. Lamb, R.; Ozsvari, B.; Lisanti, C.L.; Tanowitz, H.B.; Howell, A.; Martinez-Outschoorn, U.E.; Sotgia, F.; Lisanti, M.P. Antibiotics that target mitochondria effectively eradicate cancer stem cells, across multiple tumor types: Treating cancer like an infectious disease. Oncotarget 2015, 6, 4569-4584. [CrossRef]

42. Alistar, A.; Morris, B.B.; Desnoyer, R.; Klepin, H.D.; Hosseinzadeh, K.; Clark, C.; Cameron, A.; Leyendecker, J.; D’ Agostino, R., Jr.; Topaloglu, U.; et al. Safety and tolerability of the first-in-class agent cpi-613 in combination with modified folfirinox in patients with metastatic pancreatic cancer: A single-centre, open-label, dose-escalation, phase 1 trial. Lancet. Oncol. 2017, 18, 770-778. [CrossRef]

43. Bellio, C.; DiGloria, C.; Spriggs, D.R.; Foster, R.; Growdon, W.B.; Rueda, B.R. The metabolic inhibitor cpi-613 negates treatment enrichment of ovarian cancer stem cells. Cancers 2019, 11, 1678. [CrossRef]

44. Vasan, K.; Werner, M.; Chandel, N.S. Mitochondrial metabolism as a target for cancer therapy. Cell Metab. 2020, 32, 341-352. [CrossRef] [PubMed]

45. De Francesco, E.M.; Sotgia, F.; Lisanti, M.P. Cancer stem cells (cscs): Metabolic strategies for their identification and eradication. Biochem. J. 2018, 475, 1611-1634. [CrossRef] [PubMed]

46. Hynek, J.; Koncošová, M.; Zelenka, J.; Kř́̌̌̌ová, I.; Ruml, T.; Kubát, P.; Demel, J.; Lang, K. Phosphinatophenylporphyrins tailored for high photodynamic efficacy. Org. Biomol. Chem. 2018, 16, 7274-7281. [CrossRef]

47. Kirakci, K.; Zelenka, J.; Rumlová, M.; Cvačka, J.; Ruml, T.; Lang, K. Cationic octahedral molybdenum cluster complexes functionalized with mitochondria-targeting ligands: Photodynamic anticancer and antibacterial activities. Biomater. Sci. 2019, 7 , 1386-1392. [CrossRef]

48. Darmostuk, M.; Jurášek, M.; Lengyel, K.; Zelenka, J.; Rumlová, M.; Drašar, P.; Ruml, T. Conjugation of chlorins with spermine enhances phototoxicity to cancer cells in vitro. J. Photochem. Photobiol. BBiol. 2017, 168, 175-184. [CrossRef] 